\title{
ॠUSGS
}

sememsons

Prepared in cooperation with the

New York State Department of Environmental Conservation

Groundwater Quality in the Lake Champlain Basin, New York, 2009

Open-File Report 2011-1180 
Cover. View of Lake Champlain from the west shore of the lake 


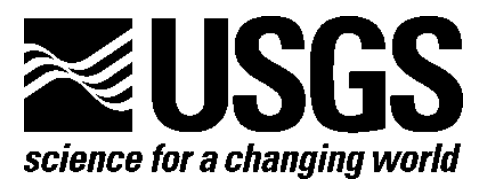

Prepared in cooperation with the New York State Department of Environmental Conservation

\section{Groundwater Quality in the Lake Champlain Basin, New York, 2009}

By Elizabeth A. Nystrom

Open-File Report 2011-1180

U.S. Department of the Interior

U.S. Geological Survey 


\section{U.S. Department of the Interior \\ KEN SALAZAR, Secretary}

\section{U.S. Geological Survey \\ Marcia K. McNutt, Director}

U.S. Geological Survey, Reston, Virginia 2011

For product and ordering information:

World Wide Web: http://www.usgs.gov/pubprod

Telephone: 1-888-ASK-USGS

For more information on the USGS-the Federal source for science about the Earth,

its natural and living resources, natural hazards, and the environment:

World Wide Web: http://www.usgs.gov

Telephone: 1-888-ASK-USGS

Suggested citation:

Nystrom, E.A., 2011, Groundwater quality in the Lake Champlain Basin, New York, 2009: U.S. Geological Survey Open-File Report 2011-1180, 42 p., at http://pubs.usgs.gov/of/2011/1180/.

Any use of trade, product, or firm names is for descriptive purposes only and does not imply endorsement by the U.S. Government.

Although this report is in the public domain, permission must be secured from the individual copyright owners to reproduce any copyrighted material contained within this report. 


\section{Contents}

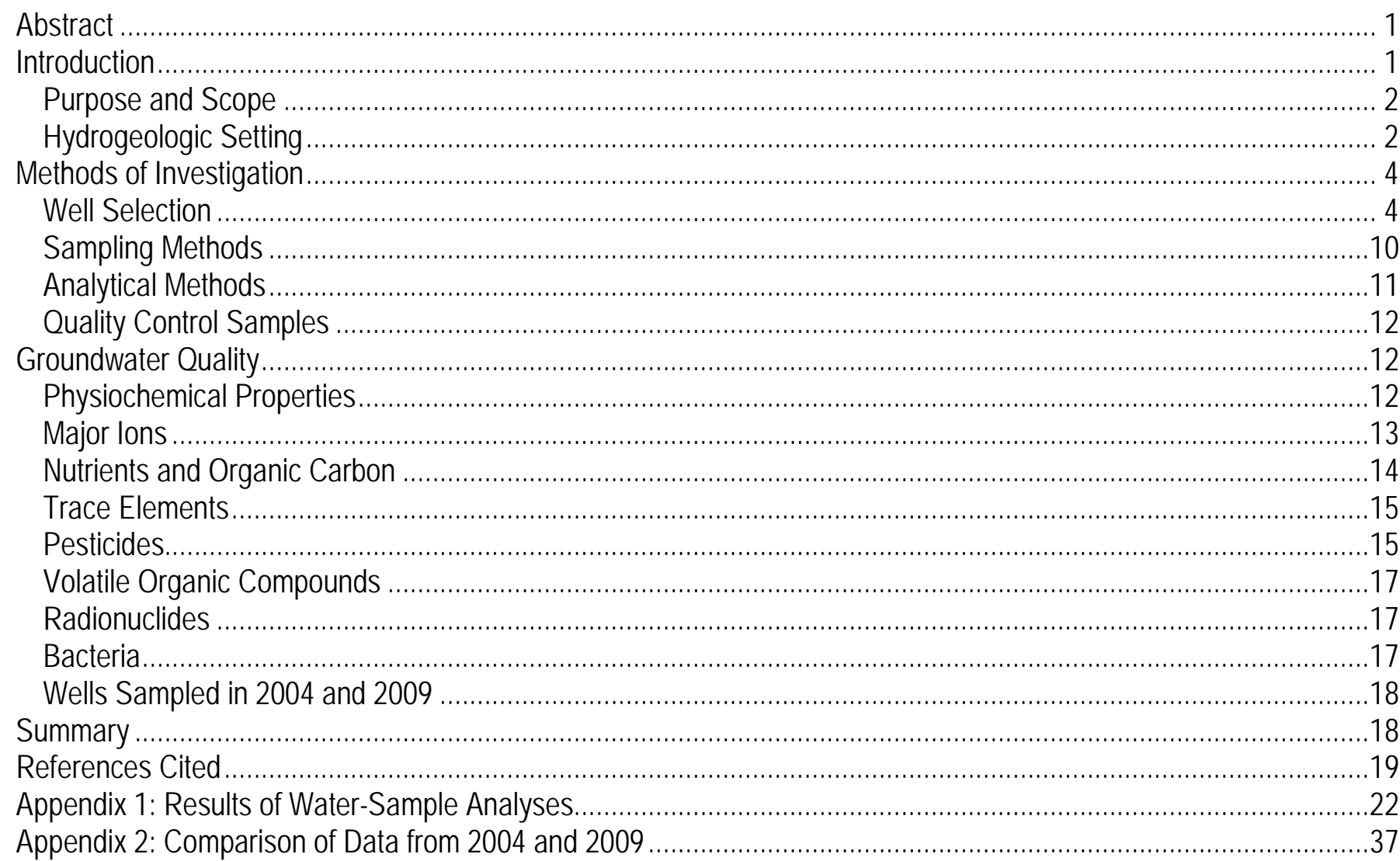

\section{Figures}

Maps showing:

1. Principal hydrologic and geographic features of the Lake Champlain Basin in New York.

2. Topography of the Lake Champlain Basin in New York, and locations of wells sampled in 2009................... 5

3. Land use and land cover of the Lake Champlain Basin in New York, and locations of wells sampled in 2009. 6

4. Generalized bedrock geology of the Lake Champlain Basin in New York, and locations of bedrock wells sampled in 2009.

5. Generalized surficial geology of the Lake Champlain Basin in New York, and locations of sand and gravel wells sampled in 2009.

\section{Tables}

1. Previous USGS 305(b) groundwater-quality sampling and reports.......................................................... 2

2. Information on wells from which water samples were collected in the Lake Champlain Basin, New York, 2009.

3. Summary of information on wells from which water samples were collected in the Lake Champlain Basin, New York, 2009.

4. Drinking-water standards and summary statistics for physiochemical properties of groundwater samples from the Lake Champlain Basin, New York, 2009. 
5. Drinking-water standards and summary statistics for concentrations of major ions in filtered groundwater samples from the Lake Champlain Basin, New York, 2009.

6. Drinking-water standards and summary statistics for concentrations of nutrients in filtered groundwater samples from the Lake Champlain Basin, New York, 2009.

7. Drinking-water standards and summary statistics for concentrations of trace elements in groundwater samples from the Lake Champlain Basin, New York, 2009

8. Drinking-water standards and summary statistics for concentrations of radionuclides in groundwater samples from the Lake Champlain Basin, New York, 2009.

\section{Appendix 1}

1-1. Constituents that were not detected in groundwater samples collected in the Lake Champlain Basin, New York, 2009.

1-2. $\quad$ Physiochemical properties of groundwater samples collected in the Lake Champlain Basin, New York, 2009.

1-3. Concentrations of major ions in groundwater samples collected in the Lake Champlain Basin, New York, 2009.

1-4. Concentrations of nutrients and organic carbon in groundwater samples collected in the Lake Champlain Basin, New York, 2009.

1-5. Concentrations of trace elements in groundwater samples collected in the Lake Champlain Basin, New York, 2009.

1-6. Concentrations of pesticides and pesticide degradates detected in groundwater samples collected in the Lake Champlain Basin, New York, 2009. .33

1-7. Concentrations of volatile organic compounds detected in groundwater samples collected in the Lake Champlain Basin, New York, 2009. 34

1-8. Activities of radionuclides in groundwater samples from the Lake Champlain Basin, New York, 2009. .........35

1-9. Bacteria in groundwater samples collected in the Lake Champlain Basin, New York, 2009..... 36

\section{Appendix 2}

2-1. Physiochemical properties and concentrations of major ions, nutrients, and bacteria in groundwater samples collected in the Lake Champlain Basin, New York, 2004 and 2009.

2-2. Concentrations of trace elements and radionuclides in groundwater samples collected in the Lake Champlain Basin, New York, 2004 and 2009.

2-3. Concentrations of pesticides in groundwater samples collected in the Lake Champlain Basin, New York, 2004 and 2009.

2-4. Concentrations of volatile organic compounds in groundwater samples collected in the Lake Champlain Basin, New York, 2004 and 2009. 
Conversion Factors, Datums, and Acronyms

\begin{tabular}{|c|c|c|}
\hline Multiply & By & To obtain \\
\hline \multicolumn{3}{|c|}{ Length } \\
\hline inch (in.) & 2.54 & centimeter (cm) \\
\hline foot $(\mathrm{ft})$ & 0.3048 & meter $(\mathrm{m})$ \\
\hline mile (mi) & 1.609 & kilometer $(\mathrm{km})$ \\
\hline \multicolumn{3}{|c|}{ Area } \\
\hline acre & 0.004047 & square kilometer $\left(\mathrm{km}^{2}\right)$ \\
\hline square mile $\left(\mathrm{mi}^{2}\right)$ & 2.590 & square kilometer $\left(\mathrm{km}^{2}\right)$ \\
\hline \multicolumn{3}{|c|}{ Volume } \\
\hline gallon (gal) & 3.785 & liter (L) \\
\hline liter (L) & 0.2642 & gallon (gal) \\
\hline \multicolumn{3}{|c|}{ Flow rate } \\
\hline gallon per minute (gal/min) & 0.06309 & liter per second (L/s) \\
\hline \multicolumn{3}{|c|}{ Pressure } \\
\hline inch of mercury at $60^{\circ} \mathrm{F}$ (in $\mathrm{Hg}$ ) & 3.377 & kilopascal (kPa) \\
\hline \multicolumn{3}{|c|}{ Radioactivity } \\
\hline picocurie per liter (pCi/L) & 0.037 & becquerel per liter $(\mathrm{Bq} / \mathrm{L})$ \\
\hline
\end{tabular}

Temperature in degrees Celsius $\left({ }^{\circ} \mathrm{C}\right)$ may be converted to degrees Fahrenheit $\left({ }^{\circ} \mathrm{F}\right)$ as follows: ${ }^{\circ} \mathrm{F}=\left(1.8 x^{\circ} \mathrm{C}\right)+32$

Temperature in degrees Fahrenheit $\left({ }^{\circ} \mathrm{F}\right)$ may be converted to degrees Celsius $\left({ }^{\circ} \mathrm{C}\right)$ as follows: ${ }^{\circ} \mathrm{C}=\left({ }^{\circ} \mathrm{F}-32\right) / 1.8$

Vertical coordinate information is referenced to the North American Vertical Datum of 1988 (NAVD 88).

Elevation, as used in this report, refers to distance above the vertical datum.

Specific conductance is given in microsiemens per centimeter at 25 degrees Celsius $\left(\mu \mathrm{S} / \mathrm{cm}\right.$ at $\left.25^{\circ} \mathrm{C}\right)$.

Concentrations of chemical constituents in water are given either in milligrams per liter (mg/L) or micrograms per liter $(\mu \mathrm{g} / \mathrm{L})$.

Radon-222 activities are given in picocuries per liter (pCi/L). 


$\begin{array}{ll}\text { Acronyms used in this report } \\ \text { AMCL } & \text { Alternative maximum contaminant level } \\ \text { CFCL } & \text { USGS Chlorofluorocarbon Laboratory } \\ \text { CFU } & \text { Colony-forming units } \\ \text { CIAT } & \text { 2-Chloro-4-isopropylamino-6-amino-s-triazine } \\ \text { cICP-MS } & \text { Collision/reaction cell inductively coupled plasma-mass spectrometry } \\ \text { E. coli } & \text { Escherichia coli } \\ \text { GC-MS } & \text { Gas chromatography-mass spectrometry } \\ \text { GPS } & \text { Global positioning system } \\ \text { HPLC-MS } & \text { High-performance liquid chromatography-mass spectrometry } \\ \text { ICP-AES } & \text { Inductively coupled plasma-atomic emission spectrometry } \\ \text { ICP-MS } & \text { Inductively coupled plasma-mass spectrometry } \\ \text { ICP-OES } & \text { Inductively coupled plasma-optical emission spectrometry } \\ \text { LRL } & \text { Laboratory reporting level } \\ \text { MCL } & \text { Maximum contaminant level } \\ \text { MTBE } & \text { Methyl tert-butyl ether } \\ \text { NWQL } & \text { USGS National Water Quality Laboratory } \\ \text { NYSDEC } & \text { New York State Department of Environmental Conservation } \\ \text { NYSDOH } & \text { New York State Department of Health } \\ \text { PVC } & \text { Polyvinyl chloride } \\ \text { RIBS } & \text { Rotating Integrated Basin Studies } \\ \text { SDWS } & \text { Secondary drinking-water standards } \\ \text { THM } & \text { Trihalomethane } \\ \text { USEPA } & \text { U.S. Environmental Protection Agency } \\ \text { USGS } & \text { U.S. Geological Survey } \\ \text { VOC } & \text { Volatile organic compound }\end{array}$




\title{
Groundwater Quality in the Lake Champlain Basin, New York, 2009
}

\author{
By Elizabeth A. Nystrom
}

\section{Abstract}

Water was sampled from 20 production and domestic wells from August through November 2009 to characterize groundwater quality in the Lake Champlain Basin in New York. Of the 20 wells sampled, 8 were completed in sand and gravel, and 12 were completed in bedrock. The samples were collected and processed by standard U.S. Geological Survey procedures and were analyzed for 147 physiochemical properties and constituents, including major ions, nutrients, trace elements, pesticides, volatile organic compounds (VOCs), radionuclides, and indicator bacteria.

Water quality in the study area is generally good, but concentrations of some constituents equaled or exceeded current or proposed Federal or New York State drinking-water standards; these were color (1 sample), pH (3 samples), sodium (3 samples), total dissolved solids (4 samples), iron (4 samples), manganese (3 samples), gross alpha radioactivity (1 sample), radon-222 (10 samples), and bacteria (5 samples). The $\mathrm{pH}$ of all samples was typically neutral or slightly basic (median 7.1); the median water temperature was $9.7^{\circ} \mathrm{C}$. The ions with the highest median concentrations were bicarbonate [median 158 milligrams per liter (mg/L)] and calcium (median $45.5 \mathrm{mg} / \mathrm{L}$ ). Groundwater in the study area is soft to very hard, but more samples were hard or very hard $\left(121 \mathrm{mg} / \mathrm{L}\right.$ or more as $\left.\mathrm{CaCO}_{3}\right)$ than were moderately hard or soft $\left(120 \mathrm{mg} / \mathrm{L}\right.$ or less as $\left.\mathrm{CaCO}_{3}\right)$; the median hardness was $180 \mathrm{mg} / \mathrm{L}$ as $\mathrm{CaCO}_{3}$. The maximum concentration of nitrate plus nitrite was $3.79 \mathrm{mg} / \mathrm{L}$ as nitrogen, which did not exceed established drinkingwater standards for nitrate plus nitrite $(10 \mathrm{mg} / \mathrm{L}$ as nitrogen $)$. The trace elements with the highest median concentrations were strontium (median 202 micrograms per liter $[\mu \mathrm{g} / \mathrm{L}]$ ), and iron (median $55 \mu \mathrm{g} / \mathrm{L}$ in unfiltered water). Six pesticides and pesticide degradates, including atrazine, fipronil, disulfoton, prometon, and two pesticide degradates, CIAT and desulfinylfipronil, were detected among five samples at concentrations of $0.02 \mu \mathrm{g} / \mathrm{L}$ or less; they included herbicides, herbicide degradates, insecticides, and insecticide degradates. Six VOCs were detected among six samples; these included a solvent, the gasoline additive methyl tert-butyl ether (MTBE), and four trihalomethanes. The highest radon-222 activities were in samples from crystalline bedrock wells (maximum 4,100 picocuries per liter [pCi/L]); half of all samples exceeded a proposed U.S. Environmental Protection Agency (USEPA) drinking-water standard of $300 \mathrm{pCi} / \mathrm{L}$. Total coliform bacteria were detected in five samples, fecal coliform bacteria were detected in one sample, and Escherichia coli (E. coli) were not detected in any sample.

\section{Introduction}

The Federal Clean Water Act Amendments of 1977 require biennial reports from states on the chemical quality of surface water and groundwater within their boundaries (U.S. Environmental Protection Agency, 1997). In 2002, the U.S. Geological Survey (USGS), in cooperation with the New York State Department of Environmental Conservation (NYSDEC), developed a program to evaluate groundwater quality throughout the major river basins in New York on a rotating basis. The USGS 305(b) waterquality monitoring program parallels the NYSDEC Rotating Integrated Basin Studies program (RIBS), which evaluates surface-water quality in 2 or 3 of the 14 major river basins in the State each year. The 
groundwater-quality program began in 2002 with a pilot study in the Mohawk River Basin and has continued throughout upstate New York since then (table 1). Sampling completed in 2008 represented the conclusion of a first round of groundwater-quality sampling throughout New York State (excluding Long Island, which is monitored through local County programs). Groundwater-quality sampling was conducted in 2009 in the Lake Champlain Basin and the Susquehanna River Basin; these basins also were sampled in 2004 as part of this study.

Table 1. Previous USGS 305(b) groundwater-quality sampling and reports.

\begin{tabular}{|l|l|l|l|}
\hline \multicolumn{1}{|c|}{ Study Area } & \multicolumn{1}{c|}{ Year } & \multicolumn{1}{c|}{ USGS Report } & \multicolumn{1}{c|}{ Reference } \\
\hline Mohawk River Basin & 2002 & Water-Data Report NY-02-1 & Butch and others, 2003 \\
\hline Chemung River Basin & 2003 & Open-File Report 2004-1329 & Hetcher-Aguila, 2005 \\
\hline Lake Champlain Basin & 2004 & Open-File Report 2006-1088 & Nystrom, 2006 \\
\hline Susquehanna River Basin & 2004 & Open-File Report 2006-1161 & Hetcher-Aguila and Eckhardt, 2006 \\
\hline Delaware River Basin & 2005 & Open-File Report 2007-1098 & Nystrom, 2007b \\
\hline Genesee River Basin & 2005 & Open-File Report 2007-1093 & Eckhardt and others, 2007 \\
\hline St. Lawrence River Basin & 2005 & Open-File Report 2007-1066 & Nystrom, 2007a \\
\hline Mohawk River Basin & 2006 & Open-File Report 2008-1086 & Nystrom, 2008 \\
\hline Western New York & 2006 & Open-File Report 2008-1140 & Eckhardt and others, 2008 \\
\hline Central New York & 2007 & Open-File Report 2009-1257 & Eckhardt and others, 2009 \\
\hline Upper Hudson River Basin & 2007 & Open-File Report 2009-1240 & Nystrom, 2009 \\
\hline Chemung River Basin & 2008 & Open-File Report 2011-1112 & Risen and Reddy, 2011a \\
\hline Eastern Lake Ontario Basin & 2008 & Open-File Report 2011-1074 & Risen and Reddy, 2011b \\
\hline Lower Hudson River Basin & 2008 & Open-File Report 2010-1197 & Nystrom, 2010 \\
\hline
\end{tabular}

\section{Purpose and Scope}

This report presents the findings of the 2009 study in the Lake Champlain Basin, in which 20 groundwater-quality samples were collected from August through November 2009. This report (1) describes the hydrogeologic setting and the methods of site selection, sample collection, and chemical analysis, (2) discusses the analytical results for physiochemical properties and concentrations of major ions, nutrients, trace elements and radionuclides, pesticides, volatile organic compounds (VOCs), and indicator bacteria, and (3) compares the results of this study to results at selected wells that were sampled in 2004 (Nystrom, 2006). Information about the sampled wells and results of the analyses are presented.

\section{Hydrogeologic Setting}

The Lake Champlain Basin encompasses 8,250 $\mathrm{mi}^{2}$ in New York, Vermont, and Quebec, Canada. This study addressed the 3,050- $\mathrm{mi}^{2}$ part of the Lake Champlain Basin that lies within New York (hereafter referred to as the "study area"; fig. 1). The study area contains parts of five counties, including Clinton, Essex, Franklin, Warren, and Washington Counties (fig. 1). Major tributaries to Lake Champlain in New York include the Ausable River, Saranac River, Great Chazy River, Boquet River, La Chute, and the Mettawee River; large lakes in the Basin include Lake Champlain and Lake George. The Champlain Canal connects Lake Champlain to the Hudson River at Fort Edward. 


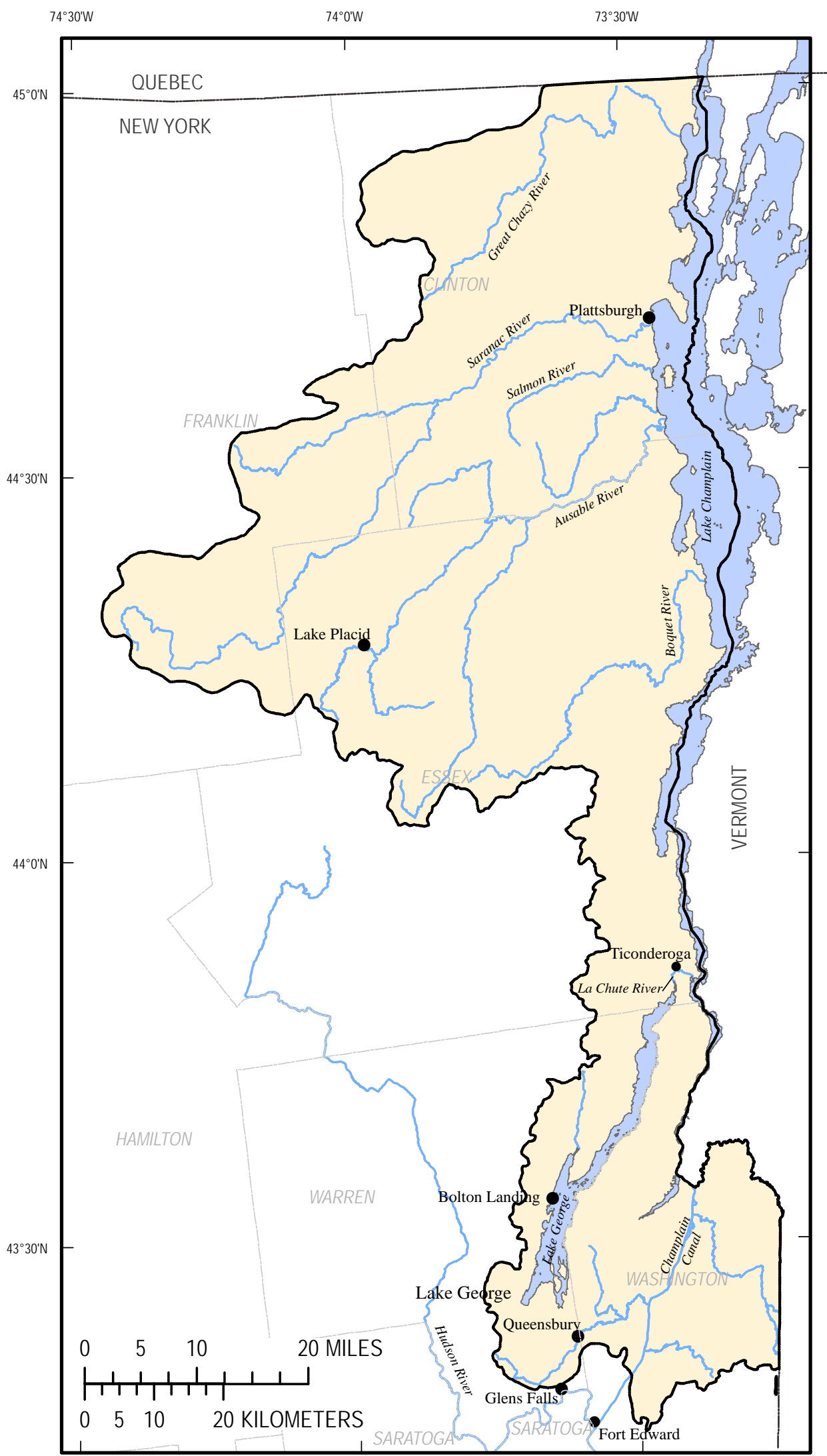

Base from U.S. geological Survey digital data, 1983, 1:100,000 Universal Transverse Mercator projection
Zone 18

Hydrology from National Hydrography Dataset

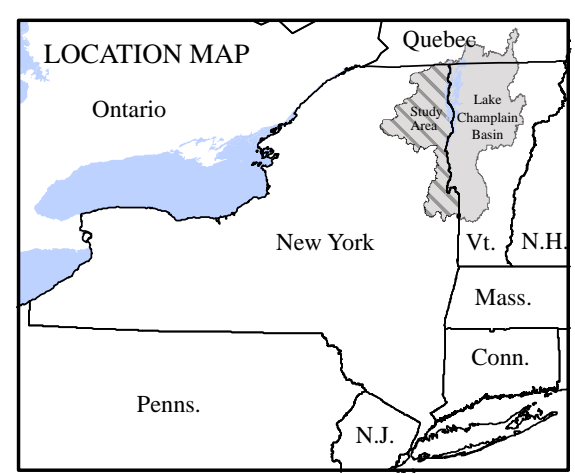

Figure 1. Principal hydrologic and geographic features of the Lake Champlain Basin in New York. 
The highest elevations in the study area are more than 5,000 $\mathrm{ft}$ above sea level (the North American Vertical Datum of 1988 [NAVD 88] along the western edge of the basin, in the Adirondack Mountains (fig. 2); the lowest elevations in the basin occur at Lake Champlain (about $100 \mathrm{ft}$ above NAVD 88). The study area is predominantly forested, especially in upland areas, with urban and agricultural uses mainly in valleys and other low-lying areas (Vogelmann and others, 2001) (fig. 3). Urban centers and adjacent developed areas in the study area include Glens Falls, Queensbury, and Plattsburgh (fig. 1).

Bedrock in the study area (fig. 4) is mainly crystalline rock with smaller areas of carbonate rock, sandstone, shale, and other rocks. The Adirondack Mountains are underlain mainly by crystalline metamorphic rock, including granitic gneiss, metanorthosite, and olivine metagabbro (Isachsen and others, 2000). The Champlain and St. Lawrence Valleys are underlain by sandstone, carbonate rocks (including limestone and dolostone), shale, and other metamorphic clastic rocks (Isachsen and others, 2000). Yields from bedrock wells in the study area vary greatly, but the carbonate units generally produce the greatest yields, and the crystalline units generally produce the smallest (Giese and Hobba, 1970).

The surficial material throughout the study area was deposited primarily during the Pleistocene epoch when the Wisconsin glaciers covered most of the Northeast (Isachsen and others, 2000). Till was deposited by glaciers over most of the study area (fig. 5); alluvial, outwash, and ice-contact sand and gravel deposits occur mainly in valleys. Glacial till generally yields low amounts of water, whereas sand and gravel deposits can form the most productive aquifers in the study area (Giese and Hobba, 1970).

\section{Methods of Investigation}

The methods used in this study, including (1) well-selection criteria, (2) sampling methods, and (3) analytical methods, were designed to maximize data precision, accuracy, and comparability. Groundwater-sample collection and processing followed standard USGS procedures as documented in the National Field Manual for the Collection of Water-Quality Data (U.S. Geological Survey, variously dated). Samples were analyzed by documented methods at the USGS National Water Quality Laboratory (NWQL) in Denver, CO; the USGS Chlorofluorocarbon Laboratory (CFCL) in Reston, VA; Eberline Services in Richmond, CA; and a New York State Department of Health (NYSDOH)-certified laboratory.

\section{Well Selection}

Wells were selected to provide adequate spatial coverage of the study area; areas of greatest groundwater use were emphasized. The final selection of each well was based on the availability of wellconstruction data and hydrogeologic information for the well and its surrounding area. The study did not target specific municipalities, industries, or agricultural practices. The 20 wells selected for sampling represent forested, developed, and agricultural areas (fig. 3). The characteristics of the wells sampled and the type of land cover surrounding each well are listed in table 2. The depths of the wells, the geologic units from which samples were collected, and the numbers of production and domestic wells are summarized in table 3. Four wells sampled in 2009 (CL149, EX155, EX535, and W534) were also sampled in 2004 (Nystrom, 2006). 


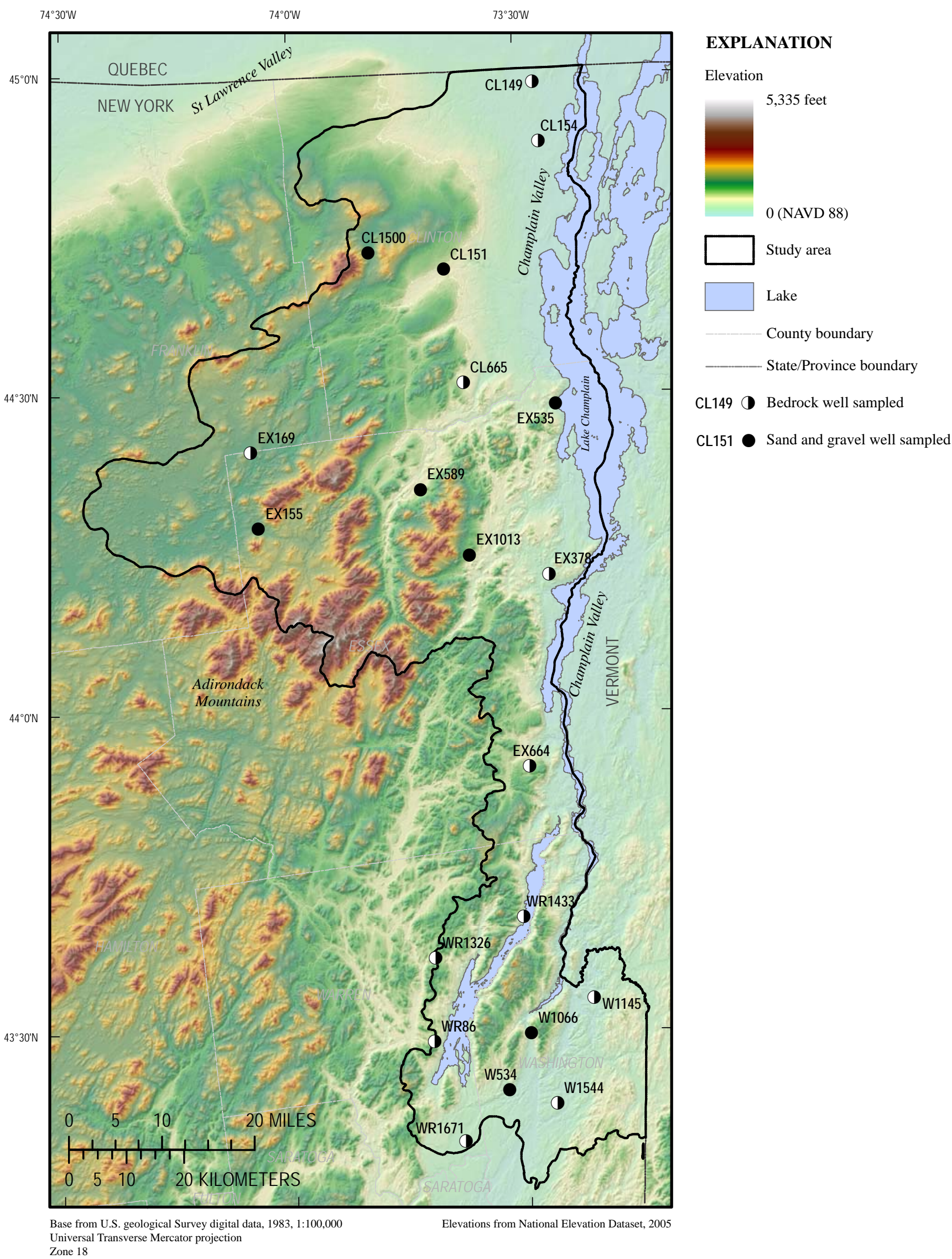

Figure 2. Topography of the Lake Champlain Basin in New York, and locations of wells sampled in 2009. 
$74^{\circ} 30^{\prime} \mathrm{W}$

$45^{\circ} \mathrm{O}^{\prime} \mathrm{N}$

$$
45^{\circ} 0^{\prime} \mathrm{N}
$$

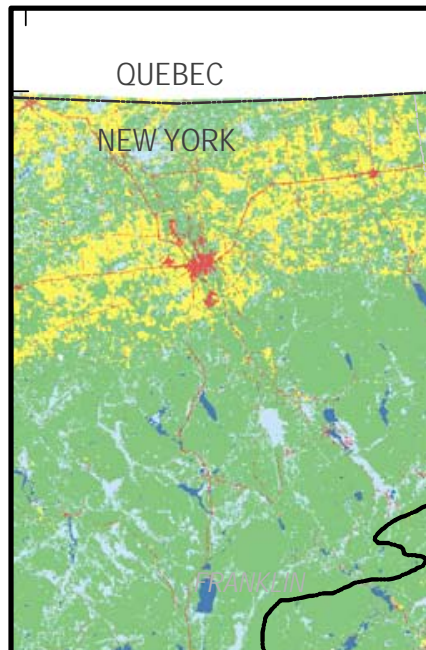

$44^{\circ} 30^{\prime} \mathrm{N}$

$44^{\circ} \mathrm{O}^{\prime} \mathrm{N}$

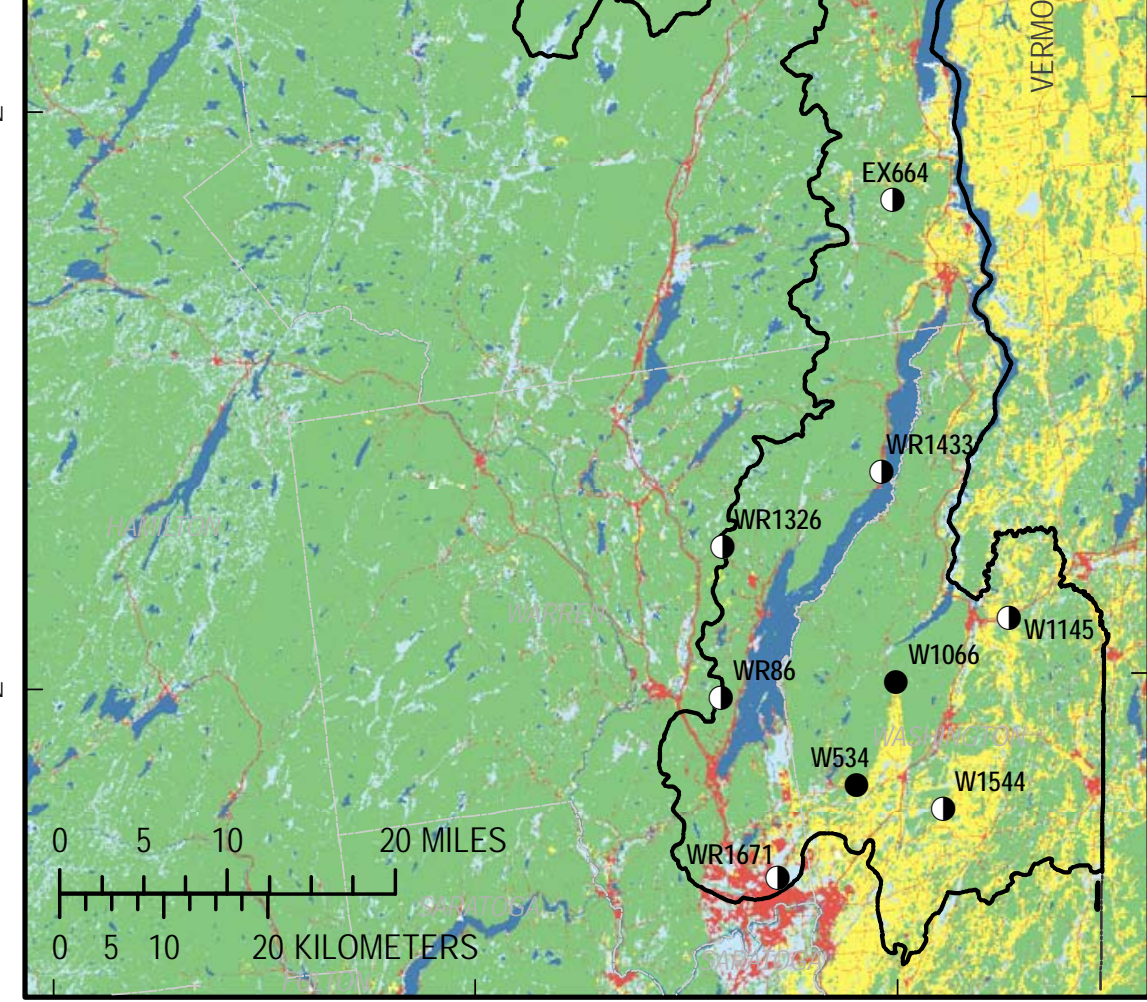

Base from U.S. geological Survey digital data, 1983, 1:100,000 Universal Transverse Mercator projection

Zone 18

Figure 3. Land use and land cover of the Lake Champlain Basin in New York, and locations of wells sampled in 2009. 


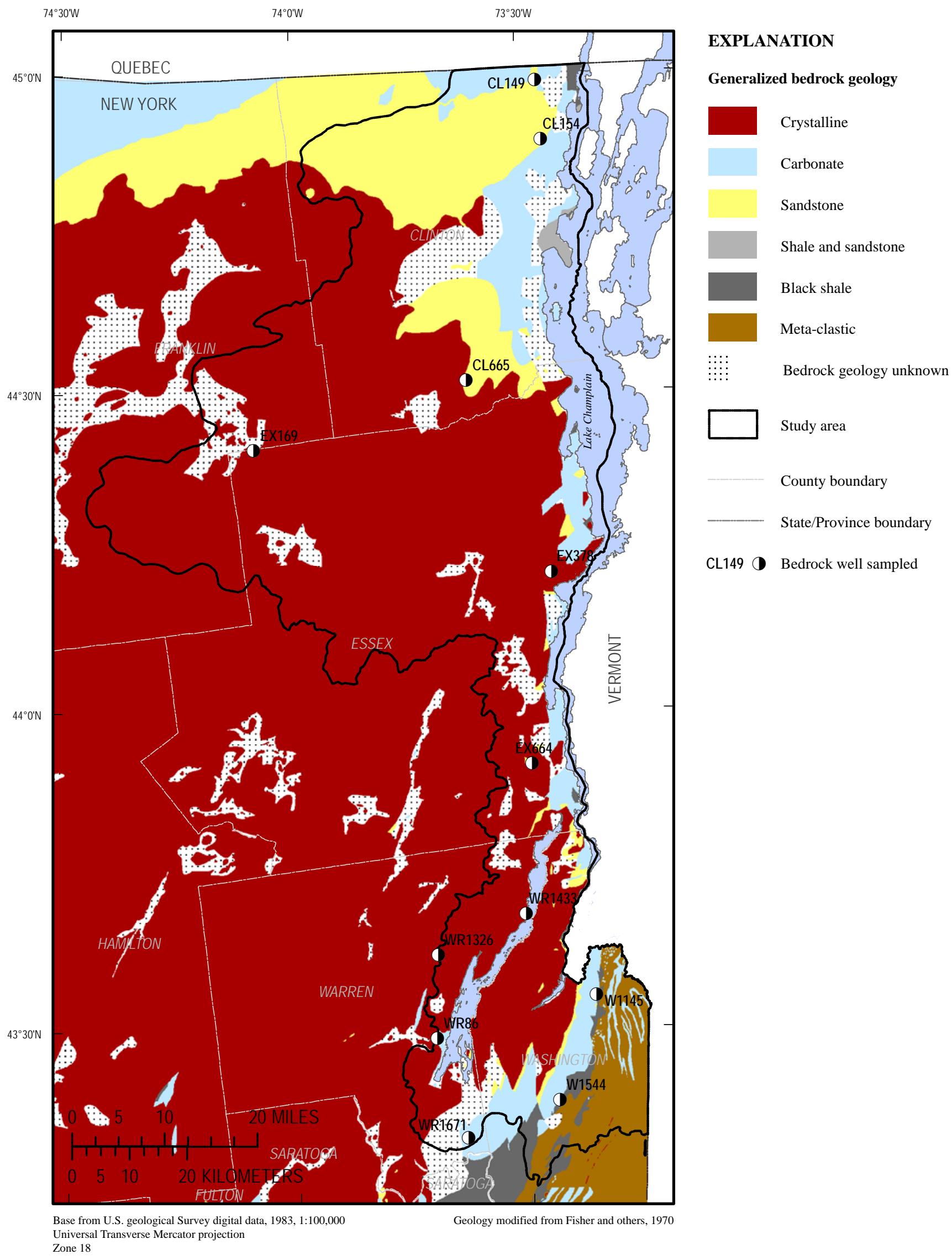

Figure 4. Generalized bedrock geology of the Lake Champlain Basin in New York, and locations of bedrock wells sampled in 2009. 


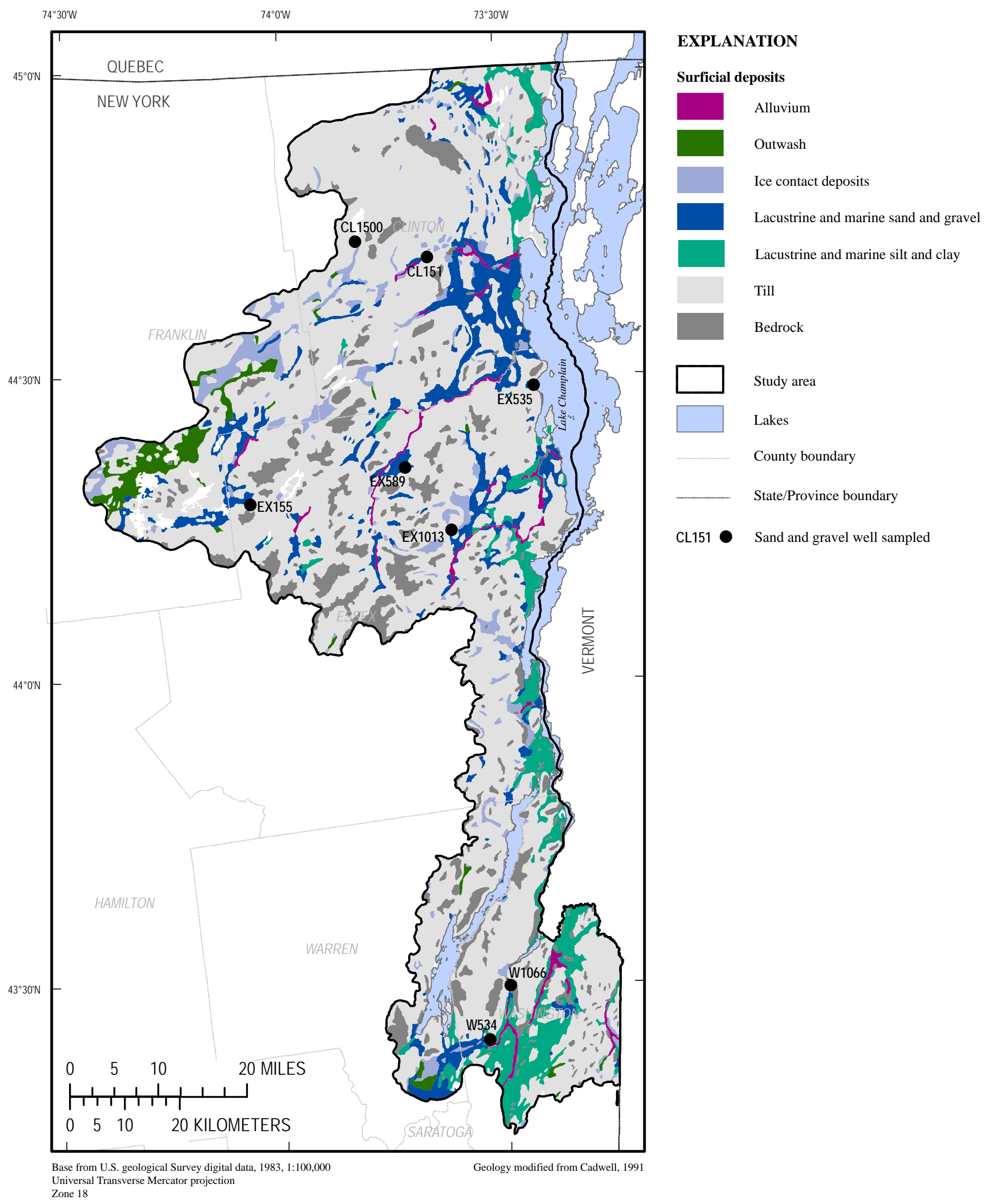

Figure 5. Generalized surficial geology of the Lake Champlain Basin in New York, and locations of sand and gravel wells sampled in 2009. 
Table 2. Information on wells from which water samples were collected in the Lake Champlain Basin, New York, 2009.

[--, unknown; Well types: P, production; D, domestic. Land cover categories: D, $\square$ developed; F, $\square$ forested;

A, $\square$ agricultural; W, $\square$ open water; WL, $\square$ wetlands. Well locations are shown in figure 2.]

\begin{tabular}{|c|c|c|c|c|c|c|c|c|c|c|}
\hline \multirow{2}{*}{$\begin{array}{c}\text { Well } \\
\text { number }^{1}\end{array}$} & \multirow[b]{2}{*}{ Date sampled } & \multirow{2}{*}{$\begin{array}{c}\text { Well } \\
\text { depth, feet } \\
\text { below land } \\
\text { surface }\end{array}$} & \multirow{2}{*}{$\begin{array}{l}\text { Casing } \\
\text { depth, feet } \\
\text { below land } \\
\text { surface }\end{array}$} & \multirow{2}{*}{$\begin{array}{l}\text { Well } \\
\text { type }\end{array}$} & \multirow[b]{2}{*}{ Bedrock type } & \multicolumn{5}{|c|}{$\begin{array}{l}\text { Land cover }{ }^{2}, \text { percentage by } \\
\text { category, within } 0.5 \text {-mile radius } \\
\text { surrounding the well }\end{array}$} \\
\hline & & & & & & $\bar{D}$ & $\mathrm{~F}$ & $A$ & W & WL \\
\hline
\end{tabular}

Sand and gravel wells

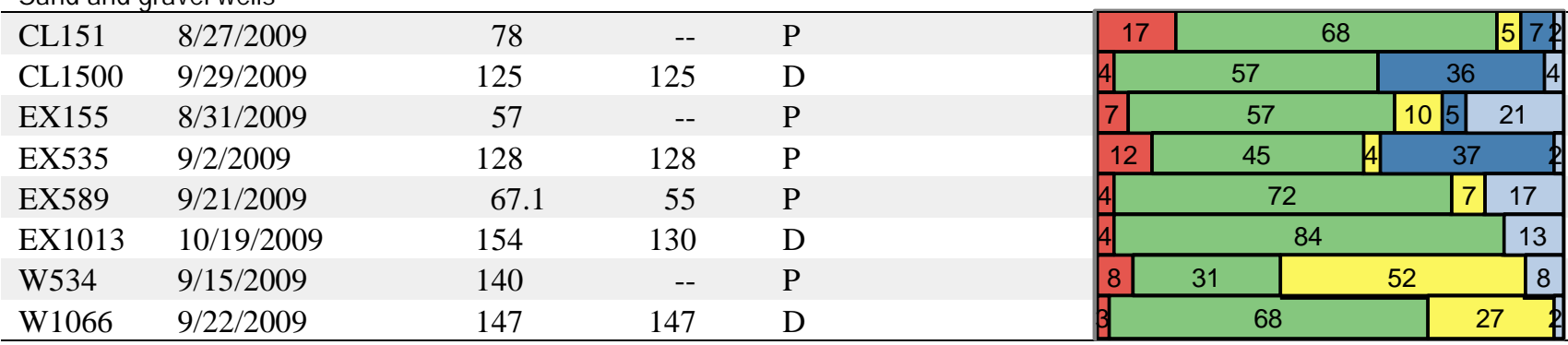

\begin{tabular}{|c|c|c|c|c|c|c|c|c|c|c|c|}
\hline CL149 & $10 / 5 / 2009$ & 137 & - & $\mathrm{P}$ & Sandstone & \multicolumn{3}{|c|}{55} & 8 & 30 & 6 \\
\hline CL154 & 9/16/2009 & -- & -- & $\mathrm{P}$ & Carbonate & 20 & 1 & 10 & \multicolumn{3}{|c|}{52} \\
\hline CL665 & $10 / 20 / 2009$ & 225 & 56 & $\mathrm{D}$ & Sandstone & \multicolumn{6}{|c|}{96} \\
\hline EX169 & 9/28/2009 & 300 & -- & $\mathrm{P}$ & Crystalline & \multicolumn{2}{|c|}{26} & \multicolumn{3}{|c|}{58} & 15 \\
\hline EX378 & 10/21/2009 & 400 & 20 & $\mathrm{D}$ & Crystalline & \multicolumn{3}{|c|}{38} & \multicolumn{3}{|c|}{57} \\
\hline EX664 & 9/30/2009 & 460 & 37 & $\mathrm{D}$ & Crystalline & \multicolumn{6}{|c|}{87} \\
\hline W1145 & 10/28/2009 & 385 & 38 & $\mathrm{D}$ & Shale & 13 & 21 & \multicolumn{4}{|c|}{61} \\
\hline W1544 & 9/15/2009 & 300 & 20 & $\mathrm{D}$ & Carbonate & \multicolumn{2}{|r|}{33} & \multicolumn{4}{|c|}{59} \\
\hline WR86 & $11 / 4 / 2009$ & 198 & -- & $\mathrm{P}$ & Crystalline & \multicolumn{6}{|c|}{94} \\
\hline WR1326 & 9/14/2009 & 265 & 20 & $\mathrm{D}$ & Crystalline & \multicolumn{6}{|c|}{85} \\
\hline WR1433 & $8 / 26 / 2009$ & 600 & 28 & $\mathrm{D}$ & Crystalline & 10 & 3 & & \multicolumn{3}{|c|}{51} \\
\hline WR1671 & $9 / 14 / 2009$ & 540 & 40 & $\mathrm{P}$ & Carbonate & \multicolumn{4}{|c|}{57} & \multicolumn{2}{|l|}{33} \\
\hline
\end{tabular}

${ }^{1}$ CL, Clinton County; EX, Essex County; W, Washington County; WR, Warren County.

${ }^{2}$ Determined from the National Land Cover Data set (Vogelmann and others, 2001).

Table 3. Summary of information on wells from which water samples were collected in the Lake Champlain Basin, New York, 2009.

\begin{tabular}{|c|c|c|c|c|}
\hline \multirow{2}{*}{\multicolumn{2}{|c|}{ Type of Well }} & \multicolumn{3}{|c|}{ Number of wells } \\
\hline & & \multirow{2}{*}{$\begin{array}{c}\text { Production } \\
5 \\
\end{array}$} & \multirow{2}{*}{$\begin{array}{c}\text { Domestic } \\
3 \\
\end{array}$} & \multirow{2}{*}{$\begin{array}{r}\text { Total } \\
8 \\
\end{array}$} \\
\hline Wells completed in sand and gravel & (57 to 154 feet deep) & & & \\
\hline Wells completed in bedrock & (137 to 600 feet deep) & 5 & 7 & 12 \\
\hline Carbonate bedrock & & 2 & 1 & 3 \\
\hline Shale bedrock & & 0 & 1 & 1 \\
\hline Sandstone bedrock & & 1 & 1 & 2 \\
\hline Crystalline bedrock & & 2 & 4 & 6 \\
\hline Total number of wells & & 10 & 10 & 20 \\
\hline
\end{tabular}


The 10 domestic wells were selected from an inventory of about 3,000 wells in the NYSDEC Water Well program database, which contains information on wells drilled since 2000. Well owners who granted permission were contacted by phone to verify well information and to arrange a convenient time for sampling.

Production wells considered for sampling were identified through the U.S. Environmental Protection Agency (USEPA) Safe Drinking Water Information System and the NYSDEC Water Well program. Well information such as depth was provided by water managers if a well-completion report was unavailable. The aquifer type indicated for sampled wells was verified through inspection of published geologic maps including Fisher and others (1970) and Cadwell (1991).

\section{Sampling Methods}

The 20 wells were sampled from August through November 2009, and samples were collected and processed in accordance with documented USGS standard operating procedures (U.S. Geological Survey, variously dated). Water samples from the domestic wells were collected before any water-treatment system to be as representative of the aquifer water quality as possible. Water samples from production wells were collected at the spigot or faucet used for collection of raw-water samples by water managers.

Typically, samples were collected from one or more $10-\mathrm{ft}$ lengths of Teflon tubing attached to the spigot. Domestic wells were purged after the tubing was connected by running to waste for at least 20 minutes at pumping rates ranging from about 2 to $5 \mathrm{gal} / \mathrm{min}$, or until at least one well-casing volume of water had passed the sampling point. Wells that had been used recently required removal of less than three well-casing volumes (U.S. Geological Survey, 2006). Domestic wells were actively pumped during sampling. At least three well-casings of water were pumped from production wells before sampling; several were pumped for 1 hour or more prior to sampling, typically at rates of about $100 \mathrm{gal} / \mathrm{min}$. During well purging, notes about the well and surrounding land and land use were taken, including a global positioning system (GPS) measurement of latitude and longitude. After the well was purged, field measurements of water temperature, $\mathrm{pH}$, specific conductance, and dissolved oxygen concentration were recorded at regular intervals until these values had stabilized, after which the sample was collected (U.S. Geological Survey, variously dated).

The flow rate for sample collection was adjusted to less than $0.5 \mathrm{gal} / \mathrm{min}$ when possible. Equipment for filtration of pesticide samples was rinsed with methanol as described in Wilde (2004). Samples were collected and preserved in the sampling chamber according to standard USGS procedures. Samples for nutrient, major-ion, and some trace-element analyses were filtered through disposable (onetime use) 0.45 - $\mu \mathrm{m}$-pore-size polyether sulfone capsule filters that were preconditioned in the laboratory with $3 \mathrm{~L}$ of deionized water the day of sample collection. Samples for pesticide analyses were filtered through baked $0.7-\mu \mathrm{m}$-pore-size glass fiber filters. Acid preservation was required for trace element, VOC, major-cation analyses, and some radiochemical analyses. Acid preservative was added after the collection of other samples to avoid the possibility of cross contamination by the acid preservative; for example, samples preserved with nitric acid were acidified after the collection of samples for nutrient analysis. Bacterial samples were collected in accordance with NYSDEC and NYSDOH protocols, except that the tap from which each water sample was collected was not flame sterilized. Water samples for radon analysis were collected through a septum chamber with a glass syringe according to standard USGS procedures. Water samples for dissolved gas analyses were filled and sealed while submerged in a beaker of water to prevent exposure to the atmosphere. Water samples analyzed by NYSDOH-certified laboratories were collected in bottles provided by the analyzing laboratory. After collection, all water samples except those for radiochemical analyses were chilled to $4^{\circ} \mathrm{C}$ or less and were kept chilled until delivery to the analyzing laboratory. Bacterial samples were hand-delivered to the analyzing laboratory within 6 hours of collection; all other samples were shipped by overnight delivery to the designated laboratories. 
Most sampling sites had easy access to a garden-hose type spigot; however, some supply wells did not. Wells CL149, CL151, EX169, and EX589 (fig. 2 and table 1) were sampled from smooth-ended taps at which water-system personnel routinely collect raw-water samples. The syringe for radon-222 sample collection at these sites was inserted directly into the flowing water in the throat of the tap to minimize sample exposure to the atmosphere.

\section{Analytical Methods}

Samples were analyzed for 147 physiochemical properties and constituents, including major ions, nutrients, trace elements, radionuclides, pesticides and pesticide degradates, VOCs, and bacteria. Physiochemical properties such as water temperature, $\mathrm{pH}$, dissolved oxygen concentration, and specific conductance were measured at the sampling site using a multiparameter meter; the multiparameter meter was contained in a flow cell at sites with garden-hose type spigots. Major ions, nutrients, total organic carbon, trace elements, radon-222, pesticides and pesticide degradates, and VOCs were analyzed at the USGS NWQL in Denver, CO. Select dissolved gases (argon, carbon dioxide, nitrogen, and methane) were analyzed at the USGS CFCL in Reston, VA. Gross alpha and gross beta radioactivities were analyzed at Eberline Services in Richmond, CA. Indicator bacteria were analyzed at the NYSDOHcertified Darrin Fresh Water Institute in Bolton Landing, NY.

Anion concentrations were measured by ion-exchange chromatography, and cation concentrations were measured by inductively coupled plasma-atomic emission spectrometry (ICP-AES), as described in Fishman (1993). Nutrients were analyzed by colorimetry, as described by Fishman (1993), and Kjeldahl digestion with photometric finish, as described by Patton and Truitt (2000). Total organic carbon samples collected on or before September 22, 2009 were analyzed by wet oxidation (method O-3100-83) for measurement by infrared detection (Wershaw and others, 1987); samples collected after this date were analyzed by high temperature combustion and catalytic oxidation for measurement by infrared detection according to Standard method 5310 (American Public Health Association, 1998). Mercury concentrations were measured through cold vapor-atomic fluorescence spectrometry according to methods described by Garbarino and Damrau (2001). Arsenic, chromium, and nickel samples were analyzed by use of collision/reaction cell inductively coupled plasma-mass spectrometry (cICP-MS), as described by Garbarino and others (2006). The remaining trace elements were analyzed by ICP-AES (Struzeski and others, 1996), inductively coupled plasma-optical emission spectrometry (ICP-OES), and inductively coupled plasma-mass spectrometry (ICP-MS) (Garbarino and Struzeski, 1998). Procedures for in-bottle digestions for trace-element analyses described by Hoffman and others (1996) were followed. Radon-222 activities were measured through liquid-scintillation counting (ASTM International, 2006). Samples for pesticide analyses were processed as described by Wilde and others (2004) and were analyzed using gas chromatography-mass spectrometry (GC-MS) and high-performance liquid chromatography-mass spectrometry (HPLC-MS), as described by Zaugg and others (1995), Sandstrom and others (2001), and Furlong and others (2001). VOCs were analyzed by GC-MS using methods described by Connor and others (1998).

Gross alpha and gross beta radioactivities were measured through gas flow proportional counting according to USEPA method 900.0 (U.S. Environmental Protection Agency, 1980). Carbon dioxide and methane concentrations were measured through gas chromatography with flame ionization detection; dissolved nitrogen gas and argon concentration were measured through gas chromatography with thermal conductivity detection. Indicator bacteria samples were tested for total coliform, fecal coliform, and Escherichia coli (E. coli) using membrane filtration through Standard Method 9222 (American Public Health Association, 1998); a heterotrophic plate count test (SM 9215 B) also was done. 


\section{Quality Control Samples}

In addition to the 20 groundwater samples, one blank sample and one concurrent replicate sample were collected for quality assurance. Nitrogen-purged VOC/pesticide-grade blank water and inorganicgrade blank water supplied by the USGS-NWQL were used for a laboratory equipment blank sample. The water for unfiltered constituents was run through a piece of the Teflon tubing used for sampling; water for filtered-water constituents was pumped through the Teflon tubing into cleaned, preconditioned filters. Quality-assurance samples were acidified in the same manner as environmental well-water samples. The only property that exceeded laboratory reporting levels (LRLs) in the blank was sample color, which was measured at 2 platinum-cobalt (Pt-Co) units (LRL 1 Pt-Co unit). The concentration differences between the replicate sample and the corresponding environmental sample were 5 percent or less for all constituents detected above the LRL in both samples, except for methane, arsenic, gross beta radioactivity, radon-222, and the heterotrophic plate count, which were detected in the replicate sample at levels close to the LRL; small differences in concentration result in large relative percent-concentration differences. No VOCs or pesticides were detected in the replicate sample.

\section{Groundwater Quality}

The 20 samples were analyzed for 147 constituents and physiochemical properties. Most (77) of these were not detected above the LRLs in any sample (appendix table 1-1). Results for the remaining 70 constituents and properties that were detected are presented in appendix 1 (tables 1-2 through 1-9). Some concentrations are reported as "estimated." Concentrations are reported as estimated where the detected value is less than the established LRL, or when recovery of a compound has been shown to be highly variable (Childress and others, 1999). Concentrations of some constituents exceeded maximum contaminant levels (MCLs) or secondary drinking-water standards (SDWS) set by the USEPA (U.S. Environmental Protection Agency, 2009) or NYSDOH (New York State Department of Health, 2007). MCLs are enforceable standards for finished water of public water supplies; they are not enforceable for private homeowner wells but are presented here as a standard for evaluation of the water-quality results. SDWS are nonenforceable drinking-water standards that typically relate to aesthetic concerns such as taste, odor, or staining of plumbing fixtures.

\section{Physiochemical Properties}

The color of samples ranged from less than $(<) 1$ to 20 Pt-Co units; the median sample color was $<2$ Pt-Co units (table 4 and appendix table 1-2). The color of one sample from a bedrock well, 20 Pt-Co units, exceeded the NYSDOH MCL and USEPA SDWS of 15 Pt-Co units. Dissolved oxygen concentration ranged from $<0.1$ to $13.6 \mathrm{mg} / \mathrm{L}$ and was generally greater in samples from sand and gravel wells (median $7.0 \mathrm{mg} / \mathrm{L}$ ) than in samples from bedrock wells (median $1.6 \mathrm{mg} / \mathrm{L}$ ). Sample pH was typically near neutral or slightly basic (median 7.1 in all wells) and ranged from 5.9 to 8.5 . The $\mathrm{pH}$ of three samples was lower than the USEPA SDWS range for $\mathrm{pH}$ (6.5 to 8.5); all three samples were from bedrock wells. Specific conductance ranged from 65 to $1,310 \mu \mathrm{S} / \mathrm{cm}$ at $25^{\circ} \mathrm{C}$, the median conductance was $412 \mu \mathrm{S} / \mathrm{cm}$ at $25^{\circ} \mathrm{C}$. Water temperature ranged from 7.9 to $15.1^{\circ} \mathrm{C}$; the median temperature was $9.7^{\circ} \mathrm{C}$. The concentration of carbon dioxide ranged from 0.5 to $61.1 \mathrm{mg} / \mathrm{L}$ and was generally greater in samples from bedrock wells (median $10.0 \mathrm{mg} / \mathrm{L}$ ) than in samples from sand and gravel wells (median 3.2 $\mathrm{mg} / \mathrm{L}$ ). Argon concentrations ranged from 0.72 to $0.96 \mathrm{mg} / \mathrm{L}$, with a median of $0.80 \mathrm{mg} / \mathrm{L}$. Nitrogen gas concentrations ranged from 20.18 to $32.98 \mathrm{mg} / \mathrm{L}$ with a median concentration of $22.60 \mathrm{mg} / \mathrm{L}$. Methane was detected in five samples with a maximum concentration of $0.072 \mathrm{mg} / \mathrm{L}$. 
Table 4. Drinking-water standards and summary statistics for physiochemical properties of groundwater samples from the Lake Champlain Basin, New York, 2009.

[All concentrations in unfiltered water except as noted; --, not applicable; <, less than; E, estimated concentration; Pt-Co units, platinum-cobalt units; $\mu \mathrm{S} / \mathrm{cm}$, microsiemens per centimeter at 25 degrees Celsius; --, not applicable]

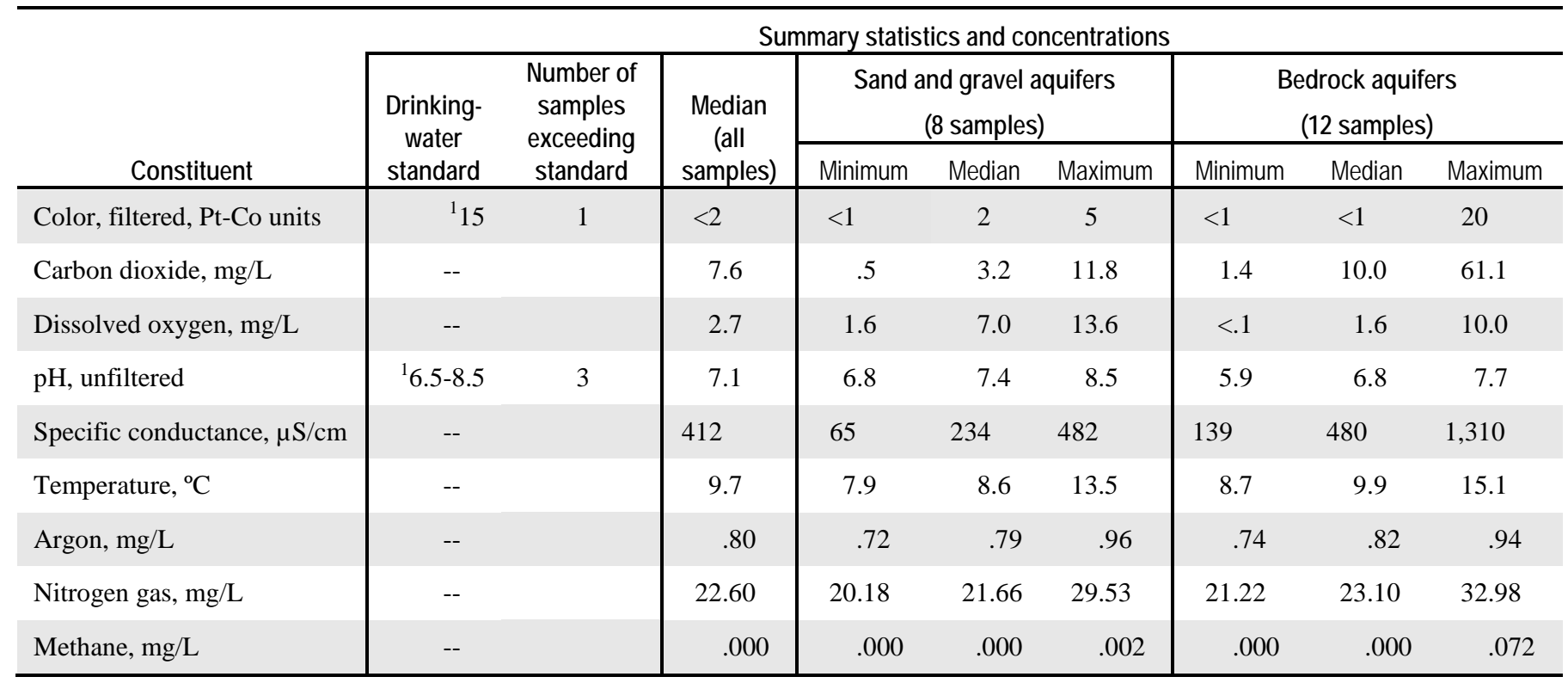

${ }^{1}$ U.S. Environmental Protection Agency Secondary Drinking Water Standard.

\section{Major lons}

The anions detected in the highest concentrations were bicarbonate (median concentration 158 $\mathrm{mg} / \mathrm{L}$ estimated, maximum concentration $413 \mathrm{mg} / \mathrm{L}$ ) and sulfate (median concentration $17.6 \mathrm{mg} / \mathrm{L}$, maximum concentration $239 \mathrm{mg} / \mathrm{L}$ ) (table 5 and appendix table 1-3). The cation detected in the highest concentration was calcium (median concentration $45.5 \mathrm{mg} / \mathrm{L}$, maximum concentration $149 \mathrm{mg} / \mathrm{L}$ ). The median concentrations of most ions were greater in samples from bedrock wells than in samples from sand and gravel wells.

The concentration of sodium in three samples from bedrock wells exceeded the USEPA nonregulatory drinking-water advisory taste threshold of $60 \mathrm{mg} / \mathrm{L}$; the maximum concentration of sodium was $148 \mathrm{mg} / \mathrm{L}$. Concentrations of chloride, fluoride, and sulfate did not exceed established drinking-water standards in any of the samples.

Water hardness ranged from 31 to $490 \mathrm{mg} / \mathrm{L}$ as $\mathrm{CaCO}_{3}$, with a median value of $180 \mathrm{mg} / \mathrm{L}$ as $\mathrm{CaCO}_{3}$. Three samples were soft ( 0 to $60 \mathrm{mg} / \mathrm{L}$ as $\mathrm{CaCO}_{3}$ ), 5 samples were moderately hard (61 to 120 $\mathrm{mg} / \mathrm{L}$ as $\left.\mathrm{CaCO}_{3}\right)$, 2 samples were hard (121 to $180 \mathrm{mg} / \mathrm{L}$ as $\left.\mathrm{CaCO}_{3}\right)$, and 10 samples were very hard (181 $\mathrm{mg} / \mathrm{L}$ as $\mathrm{CaCO}_{3}$ or more; Hem, 1985). The median hardness in samples from bedrock wells was 215 $\mathrm{mg} / \mathrm{L}$ as $\mathrm{CaCO}_{3}$ (very hard); the median in samples from sand and gravel wells was $126 \mathrm{mg} / \mathrm{L}$ as $\mathrm{CaCO}_{3}$ (hard). Alkalinity ranged from 26 to $340 \mathrm{mg} / \mathrm{L}$ as $\mathrm{CaCO}_{3}$; the median was $130 \mathrm{mg} / \mathrm{L}$ of $\mathrm{CaCO}_{3}$. The median alkalinity of samples from bedrock wells $\left(154 \mathrm{mg} / \mathrm{L}\right.$ as $\left.\mathrm{CaCO}_{3}\right)$ was higher than the median alkalinity of samples from sand and gravel wells $\left(96 \mathrm{mg} / \mathrm{L}\right.$ as $\left.\mathrm{CaCO}_{3}\right)$. Dissolved solids, dried at $180^{\circ} \mathrm{C}$, ranged from 49 to $779 \mathrm{mg} / \mathrm{L}$ with a median of $218 \mathrm{mg} / \mathrm{L}$. The dissolved solids in samples from four bedrock wells exceeded the USEPA SDWS for total dissolved solids of $500 \mathrm{mg} / \mathrm{L}$. 
Table 5. Drinking-water standards and summary statistics for concentrations of major ions in filtered groundwater samples from the Lake Champlain Basin, New York, 2009.

[All concentrations are in milligrams per liter; --, not applicable; <, less than; E, estimated concentration; ${ }^{\circ} \mathrm{C}$, degrees Celsius]

\begin{tabular}{|c|c|c|c|c|c|c|c|c|c|c|}
\hline & \multirow[b]{3}{*}{ Constituent } & \multicolumn{9}{|c|}{ Summary statistics and concentrations } \\
\hline & & \multirow{2}{*}{$\begin{array}{l}\text { Drinking- } \\
\text { water } \\
\text { standard }\end{array}$} & \multirow{2}{*}{$\begin{array}{l}\text { Number of } \\
\text { samples } \\
\text { exceeding } \\
\text { standard }\end{array}$} & \multirow{2}{*}{$\begin{array}{l}\text { Median (all } \\
\text { samples) }\end{array}$} & \multicolumn{3}{|c|}{$\begin{array}{c}\text { Sand and gravel aquifers } \\
\text { (8 samples) }\end{array}$} & \multicolumn{3}{|c|}{$\begin{array}{c}\text { Bedrock aquifers } \\
\text { (12 samples) }\end{array}$} \\
\hline & & & & & Minimum & Median & Maximum & Minimum & Median & Maximum \\
\hline \multirow{4}{*}{ 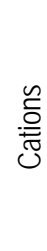 } & Calcium & -- & & 45.5 & 8.68 & 33.2 & 57.1 & 15.4 & 53.5 & 149 \\
\hline & Magnesium & -- & & 13.8 & 2.37 & 9.98 & 27.0 & 3.67 & 16.0 & 56.0 \\
\hline & Potassium & -- & & .88 & .33 & .78 & .96 & .24 & 1.20 & 11.0 \\
\hline & Sodium & ${ }^{1} 60$ & 3 & 6.34 & 1.79 & 3.44 & 6.55 & 2.10 & 19.2 & 148 \\
\hline \multirow{5}{*}{$\stackrel{\mathscr{0}}{\frac{0}{2}}$} & Bicarbonate & -- & & E 158 & E 32 & E 116 & 277 & E 54 & 187 & 413 \\
\hline & Chloride & ${ }^{2,3} 250$ & 0 & 6.66 & .43 & 1.49 & 26.5 & .89 & 20.0 & 210 \\
\hline & Fluoride & $\begin{array}{r}{ }^{4} 4.0 \\
{ }^{2} 2.2 \\
{ }^{3} 2\end{array}$ & $\begin{array}{l}0 \\
0 \\
0\end{array}$ & .10 & $<.08$ & E.06 & .10 & Е .08 & .20 & .80 \\
\hline & Silica & -- & & 13.8 & 9.52 & 15.2 & 19.0 & 5.57 & 11.0 & 18.7 \\
\hline & Sulfate & ,3,3250 & 0 & 17.6 & 5.96 & 9.67 & 29.6 & 8.01 & 21.2 & 239 \\
\hline \multicolumn{2}{|c|}{ Hardness as $\mathrm{CaCO}_{3}$} & & & 180 & 31 & 126 & 250 & 55 & 215 & 490 \\
\hline \multicolumn{2}{|c|}{ Alkalinity as $\mathrm{CaCO}_{3}$} & & & 130 & 26 & 96 & 228 & 44 & 154 & 340 \\
\hline \multicolumn{2}{|c|}{$\begin{array}{l}\text { Dissolved solids, dried } \\
\text { at } 180^{\circ} \mathrm{C}\end{array}$} & ${ }^{3} 500$ & 4 & 218 & 49 & 148 & 268 & 81 & 289 & 779 \\
\hline
\end{tabular}

${ }^{1}$ U.S. Environmental Protection Agency Drinking Water Advisory Taste Threshold.

${ }^{2}$ New York State Department of Health Maximum Contaminant Level.

${ }^{3}$ U.S. Environmental Protection Agency Secondary Drinking Water Standard.

${ }^{4}$ U.S. Environmental Protection Agency Maximum Contaminant Level.

\section{Nutrients and Organic Carbon}

The dominant nutrient detected was nitrate, reported as nitrate plus nitrite, as nitrogen $(\mathrm{N})$ in this report. Concentrations of ammonia ranged from $<0.020$ to $0.474 \mathrm{mg} / \mathrm{L}$ as nitrogen $(\mathrm{N})$. Nitrite was detected in only one sample at a concentration of $0.002 \mathrm{mg} / \mathrm{L}$ as $\mathrm{N}$; the concentration of nitrite did not exceed the USEPA and NYSDOH MCLs ( $1 \mathrm{mg} / \mathrm{L}$ as $\mathrm{N}$ ) in any sample. Concentrations of nitrate ranged from $<0.04$ to $3.79 \mathrm{mg} / \mathrm{L}$ as $\mathrm{N}$ (table 6 and appendix table 1-4); the median nitrate concentration was 0.15 $\mathrm{mg} / \mathrm{L}$ as $\mathrm{N}$. None of the water samples equaled or exceeded the USEPA and NYSDOH MCL of $10 \mathrm{mg} / \mathrm{L}$ for nitrate-N. Orthophosphate was detected in all samples; concentrations ranged from an estimated concentration of 0.004 to $0.086 \mathrm{mg} / \mathrm{L}$ as phosphorus $(\mathrm{P})$. Total organic carbon was detected in 15 samples; the maximum concentration was $1.5 \mathrm{mg} / \mathrm{L}$. 
Table 6. Drinking-water standards and summary statistics for concentrations of nutrients in filtered groundwater samples from the Lake Champlain Basin, New York, 2009.

[All concentrations in milligrams per liter. N, nitrogen; P, phosphorus; --, not applicable; <, less than; E, estimated concentration.]

\begin{tabular}{|c|c|c|c|c|c|c|c|c|c|}
\hline \multirow[b]{3}{*}{ Constituent } & \multicolumn{9}{|c|}{ Summary statistics and concentrations } \\
\hline & \multirow{2}{*}{$\begin{array}{l}\text { Drinking- } \\
\text { water } \\
\text { standard }\end{array}$} & \multirow{2}{*}{$\begin{array}{l}\text { Number of } \\
\text { samples } \\
\text { exceeding } \\
\text { standard }\end{array}$} & \multirow{2}{*}{$\begin{array}{l}\text { Median } \\
\text { (all } \\
\text { samples) } \\
\end{array}$} & \multicolumn{3}{|c|}{$\begin{array}{c}\text { Sand and gravel aquifers } \\
\text { (8 samples) }\end{array}$} & \multicolumn{3}{|c|}{$\begin{array}{c}\text { Bedrock aquifers } \\
\text { (12 samples) }\end{array}$} \\
\hline & & & & Minimum & Median & Maximum & Minimum & Median & Maximum \\
\hline Ammonia plus organic $\mathrm{N}$, as $\mathrm{N}$ & -- & & $<0.10$ & $<0.10$ & $<0.10$ & $<0.10$ & $<0.10$ & $<0.10$ & 0.53 \\
\hline Ammonia $\left(\mathrm{NH}_{3}\right)$, as $\mathrm{N}$ & -- & & $<.020$ & $<.020$ & $<.020$ & E .014 & $<.020$ & $<.020$ & .474 \\
\hline $\begin{array}{l}\text { Nitrate plus nitrate }\left(\mathrm{NO}_{2}+\right. \\
\left.\mathrm{NO}_{3}\right) \text {, as N }\end{array}$ & 1,210 & 0 & .15 & $<.04$ & .18 & 3.79 & $<.04$ & .06 & 2.33 \\
\hline Nitrite $\left(\mathrm{NO}_{2}\right)$, as $\mathrm{N}$ & 1,21 & 0 & $<.002$ & $<.002$ & $<.002$ & $<.002$ & $<.002$ & $<.002$ & .002 \\
\hline Orthophosphate $\left(\mathrm{PO}_{4}\right)$, as $\mathrm{P}$ & -- & & .010 & E .004 & .014 & .050 & E.005 & E .008 & .086 \\
\hline $\begin{array}{l}\text { Total organic carbon (TOC), } \\
\text { unfiltered }\end{array}$ & -- & & .6 & $<.6$ & E.5 & .8 & $<.6$ & .6 & 1.5 \\
\hline
\end{tabular}

${ }^{1}$ U.S. Environmental Protection Agency Maximum Contaminant Level.

${ }^{2}$ New York State Department of Health Maximum Contaminant Level.

\section{Trace Elements}

The highest median concentrations for the trace-element samples were of strontium (median 202 $\mu \mathrm{g} / \mathrm{L}$ ), iron (median $55 \mu \mathrm{g} / \mathrm{L}$ in unfiltered water; $4 \mu \mathrm{g} / \mathrm{L}$ in filtered water), barium (median $14.6 \mu \mathrm{g} / \mathrm{L}$ ), boron (median $8.4 \mu \mathrm{g} / \mathrm{L}$ ), and manganese (median $5.1 \mu \mathrm{g} / \mathrm{L}$ in unfiltered water and $3.6 \mu \mathrm{g} / \mathrm{L}$ in filtered water) (table 7 and appendix table 1-5). The highest detected trace-element concentration $(3,020 \mu \mathrm{g} / \mathrm{L})$ was for strontium in a sample from a bedrock well. The concentration of iron in four unfiltered samples from three bedrock wells and one sand and gravel well, and one filtered sample from a sand and gravel well exceeded the USEPA SDWS and NYSDOH MCL for iron of $300 \mu \mathrm{g} / \mathrm{L}$. The concentration of manganese in three unfiltered and three filtered samples from bedrock wells exceeded the USEPA SDWS of $50 \mu \mathrm{g} / \mathrm{L}$; the NYSDOH MCL of $300 \mu \mathrm{g} / \mathrm{L}$ was not exceeded in any sample. Drinking-water standards for aluminum, antimony, arsenic, barium, beryllium, cadmium, chromium, copper, lead, mercury, selenium, silver, thallium, and zinc were not exceeded in any of the water samples. Antimony, mercury, and thallium were not detected in any of the samples (appendix table 1-1).

\section{Pesticides}

Pesticides were rarely detected in the water samples and all detected concentrations were in the hundredths or thousandths of a microgram per liter. Six pesticides and pesticide degradates were detected in five samples (appendix table 1-6). Three of the pesticides detected are broadleaf herbicides or their degradates; three are insecticides or their degradates. Pesticides were detected in two samples from sand and gravel wells and in three samples from bedrock wells. The highest pesticide concentration (maximum $0.02 \mu \mathrm{g} / \mathrm{L})$ was for disulfoton.

CIAT (2-chloro-4-isopropylamino-6-amino-s-triazine, or deethyl atrazine), a degradate product of triazine herbicides including atrazine, was detected in four samples with an estimated maximum concentration of $0.003 \mu \mathrm{g} / \mathrm{L}$, and the herbicide atrazine was detected in two samples with an estimated maximum concentration of $0.002 \mu \mathrm{g} / \mathrm{L}$. The remaining four pesticides — desulfinylfipronil (an insecticide degradate), disulfoton (an insecticide), fipronil (an insecticide), and prometon (an herbicide)—were detected in one sample each. One sample (EX378) had detections of four pesticides and another sample 
(W1544) had detections of three pesticides. No pesticide concentrations exceeded established drinkingwater standards; pesticide degradates are not currently regulated.

Table 7. Drinking-water standards and summary statistics for concentrations of trace elements in groundwater samples from the Lake Champlain Basin, New York, 2009.

[ $\mu \mathrm{g} / \mathrm{L}$, micrograms per liter; <, less than; E, estimated concentration; --, not applicable]

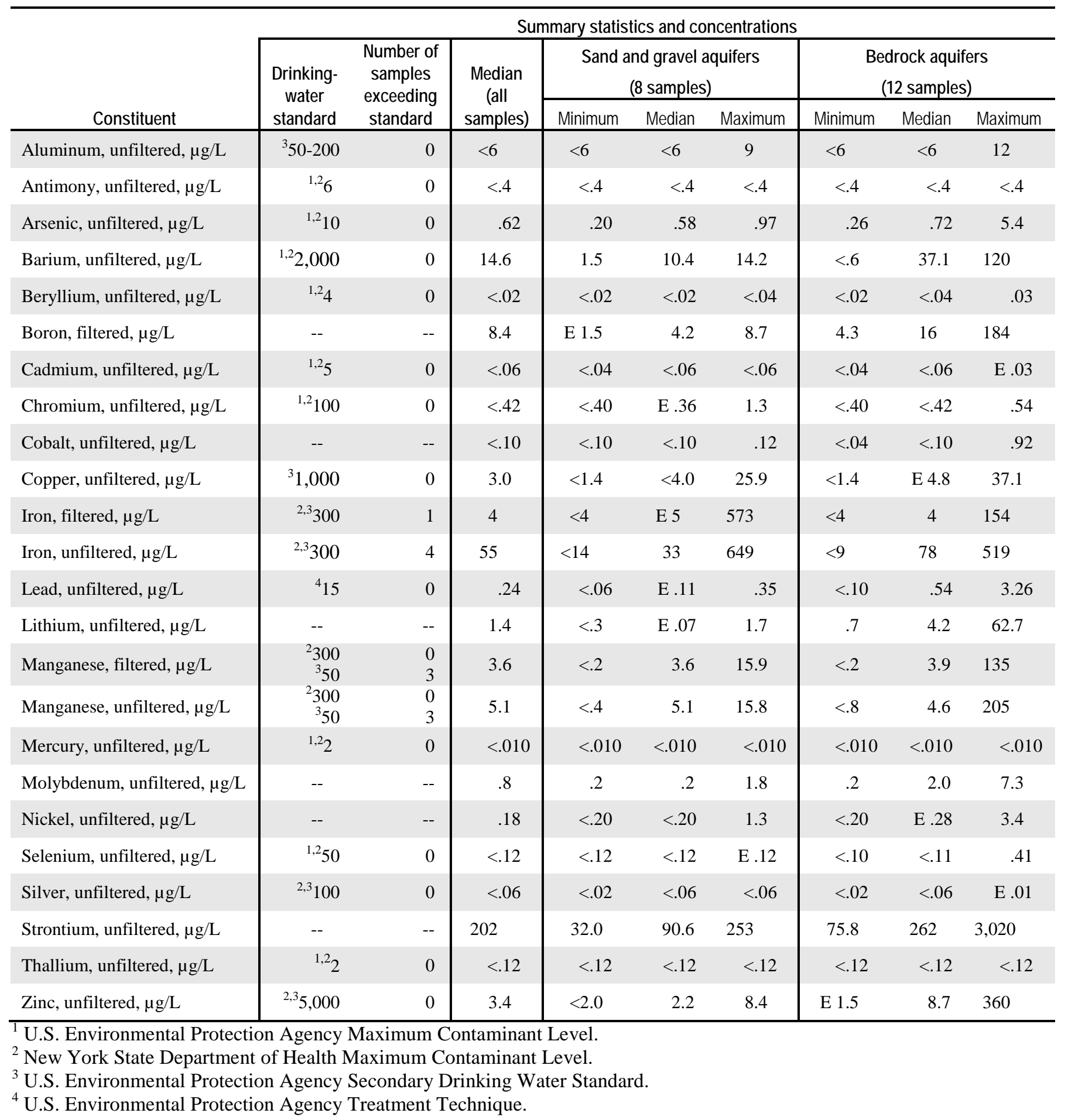




\section{Volatile Organic Compounds}

Six VOCs were detected in untreated water samples from six wells-one sand and gravel well and five bedrock wells (appendix table 1-7). Four wells had detections of one VOC each, one well (CL154) had detections of four VOCs, and one well (CL149) had detections of five VOCs. The VOCs detected include 1,1-dichloroethene, detected in one sample with a concentration of $0.3 \mu \mathrm{g} / \mathrm{L}$; methyl tert-butyl ether (MTBE), a gasoline additive, detected in two samples with a maximum concentration of $6.0 \mu \mathrm{g} / \mathrm{L}$; and four trihalomethanes (THMs). THMs are byproducts that form when chlorine or bromine are used as disinfectants; they are also used as solvents. Bromodichloromethane was detected in two samples; the maximum concentration was $4.4 \mu \mathrm{g} / \mathrm{L}$. Tribromomethane was detected in two samples; the maximum concentration was $11.8 \mu \mathrm{g} / \mathrm{L}$. Dibromochloromethane was detected in two samples; the maximum concentration was $7.8 \mu \mathrm{g} / \mathrm{L}$. Trichloromethane (chloroform) was detected in four samples; the maximum concentration was $5.0 \mu \mathrm{g} / \mathrm{L}$. The USEPA and NYSDOH MCLs for total THMs, $80 \mu \mathrm{g} / \mathrm{L}$, was not exceeded in any sample; the maximum total THM concentration was $21.6 \mu \mathrm{g} / \mathrm{L}$ in the sample from well CL149.

\section{Radionuclides}

Gross alpha-particle radioactivity ranged from non-detectable levels to $15 \mathrm{pCi} / \mathrm{L}$; the median activity was $1.2 \mathrm{pCi} / \mathrm{L}$ (table 8 and appendix table 1-8). The gross alpha radioactivity in one sample equaled the USEPA and NYSDOH MCLs for gross alpha of $15 \mathrm{pCi} / \mathrm{L}$. Gross beta-particle radioactivity ranged from non-detectable levels to $9.7 \mathrm{pCi} / \mathrm{L}$. The USEPA and NYSDOH MCLs for gross beta radioactivity are expressed as a dose of 4 millirem per year. Radon-222 activities in the water samples ranged from 19 to $4,100 \mathrm{pCi} / \mathrm{L}$; the median was $240 \mathrm{pCi} / \mathrm{L}$. The median radon-222 activity was $155 \mathrm{pCi} / \mathrm{L}$ in samples from sand and gravel wells and was $355 \mathrm{pCi} / \mathrm{L}$ in samples from bedrock wells. Radon is currently not regulated in drinking water; however, the USEPA has proposed a two-part standard for radon in community drinking-water systems: (1) a 300 pCi/L MCL for areas that do not implement an indoor-air radon mitigation program, and (2) an alternative MCL (AMCL) of 4,000 pCi/L for areas that do (U.S. Environmental Protection Agency, 1999). Activities in 10 (half) of the samples exceeded the proposed MCL. The activity in one sample exceeded the proposed AMCL; this sample was from a bedrock well. The maximum concentration of uranium was $6.41 \mu \mathrm{g} / \mathrm{L}$ in a sample from a bedrock well; the concentration of uranium did not exceed the USEPA and NYSDOH MCLs of $30 \mu \mathrm{g} / \mathrm{L}$ in any sample. The two wells with the highest uranium concentrations also had the highest radon-222 activities. The median activities or concentrations of all four measured radionuclides were higher in samples from bedrock wells than in samples from sand and gravel wells.

\section{Bacteria}

Coliform bacteria were detected in five samples (appendix table 1-9). Fecal coliform bacteria were detected in one sample. E. coli were not detected in any sample. The NYSDOH and USEPA MCL for total coliform bacteria is exceeded when five percent of samples of finished water collected in one month test positive for total coliform (if 40 or more samples are collected per month) or when two samples test positive for total coliform (if fewer than 40 samples are collected per month). The heterotrophic plate count ranged from $<1$ colony-forming unit (CFU) per milliliter $(\mathrm{mL})$ to $34 \mathrm{CFU} / \mathrm{mL}$. The USEPA MCL for the heterotrophic plate count is $500 \mathrm{CFU} / \mathrm{mL}$; this limit was not exceeded in any sample. 
Table 8. Drinking-water standards and summary statistics for concentrations of radionuclides in groundwater samples from the Lake Champlain Basin, New York, 2009.

[pCi/L, picocuries per liter, mrem/yr, millirem per year; --, not applicable; <, less than]

\begin{tabular}{|c|c|c|c|c|c|c|c|c|c|}
\hline \multirow{2}{*}{ Constituent } & \multicolumn{9}{|c|}{ Summary statistics and concentrations } \\
\hline & $\begin{array}{l}\text { Drinking- } \\
\text { water } \\
\text { standard }\end{array}$ & $\begin{array}{l}\text { Number of } \\
\text { samples } \\
\text { exceeding } \\
\text { standard }\end{array}$ & $\begin{array}{c}\text { Median } \\
\text { (all } \\
\text { samples) }\end{array}$ & \multicolumn{3}{|c|}{$\begin{array}{c}\text { Sand and gravel aquifers } \\
\text { (8 samples) }\end{array}$} & \multicolumn{3}{|c|}{$\begin{array}{c}\text { Bedrock aquifers } \\
\text { (12 samples) }\end{array}$} \\
\hline $\begin{array}{l}\text { Gross alpha radioactivity, } \\
\text { unfiltered, pCi/L }\end{array}$ & 1,215 & 0 & 1.2 & $<0.55$ & $<1.3$ & 2.0 & $<.81$ & 1.3 & 15 \\
\hline $\begin{array}{l}\text { Gross beta radioactivity, } \\
\text { unfiltered, } \mathrm{pCi} / \mathrm{L}\end{array}$ & $\begin{array}{l}{ }^{1,2} 4 \\
\text { mrem/yr }\end{array}$ & -- & 1.2 & $<.82$ & $<1.1$ & 1.1 & $<1.1$ & 2.2 & 9.7 \\
\hline Radon-222, unfiltered, pCi/L & $\begin{array}{r}{ }^{3} 300 \\
{ }^{4} 4,000\end{array}$ & $\begin{array}{r}10 \\
1\end{array}$ & 240 & 72 & 155 & 380 & 19 & 355 & 4,100 \\
\hline Uranium, unfiltered, $\mu \mathrm{g} / \mathrm{L}$ & 1,230 & 0 & .470 & E .012 & .236 & .585 & .069 & 2.20 & 6.41 \\
\hline
\end{tabular}

${ }^{1}$ U.S. Environmental Protection Agency Maximum Contaminant Level.

${ }^{2}$ New York State Department of Health Maximum Contaminant Level.

${ }^{3}$ U.S. Environmental Protection Agency Proposed Maximum Contaminant Level.

${ }^{4}$ U.S. Environmental Protection Agency Proposed Alternative Maximum Contaminant Level.

\section{Wells Sampled in 2004 and 2009}

Four of the wells sampled in 2009 (wells CL149, EX155, EX535, and W534) were sampled previously in 2004 as part of this study. Of the 147 constituents and physiochemical properties for which samples were analyzed in 2009, 140 were common to 2004 and 2009 analyses (appendix tables 2-1 through 2-4). The differences between 2004 and 2009 results for a single well were typically smaller than those between the results from different wells.

\section{Summary}

Groundwater samples were collected from August through November 2009 from 8 wells completed in sand and gravel and 12 wells completed in bedrock to characterize the groundwater quality in the Lake Champlain Basin in New York State. The sand and gravel wells sampled ranged from 57 to $154 \mathrm{ft}$ in depth; the bedrock wells ranged from 137 to $600 \mathrm{ft}$ in depth and were typically completed in crystalline bedrock. Ten of the 20 wells sampled were production wells and 10 were domestic wells. Of the 147 major ion, nutrient, trace-element, pesticide, VOC, radionuclide, and bacteria constituents, 77 were not detected in any of the samples.

The samples generally indicated good water quality, although properties and concentrations of some constituents - color, $\mathrm{pH}$, sodium, total dissolved solids, iron, manganese, gross alpha-particle radioactivity, radon-222, and bacteria - equaled or exceeded primary, secondary, or proposed drinkingwater standards. The constituents most frequently detected in concentrations exceeding drinking-water standards were radon-222 (10 samples had concentrations greater than the USEPA proposed MCL of 300 $\mathrm{pCi} / \mathrm{L}$ ), coliform bacteria (5 samples with detections), iron (4 unfiltered samples with concentrations greater than the USEPA SDWS and NYSDOH MCL of $300 \mu \mathrm{g} / \mathrm{L}$ ), and total dissolved solids (4 samples with dissolved solids greater than the USEPA SDWS of $500 \mathrm{mg} / \mathrm{L}$ ).

Sample $\mathrm{pH}$ was typically near neutral or slightly basic. Water hardness ranged from soft to very hard; more samples were hard than were soft. The ions detected in the highest median concentrations were bicarbonate, calcium, and sulfate. The dominant nutrient was nitrate, but concentrations of nitrate did not exceed established drinking-water standards. Strontium was the trace element with the highest median concentrations. The highest radon-222 activities were in samples from bedrock wells completed 
in crystalline rock (maximum 4,100 pCi/L). Six pesticides and pesticide degradates were detected in five samples - two samples from sand and gravel wells and three from bedrock wells-most were trace-level detections of broadleaf herbicides, insecticides, or their degradates. Six VOCs were detected in six samples, including MTBE and four trihalomethanes (disinfection byproducts). Coliform bacteria were detected in five samples. Fecal coliform bacteria were detected in one sample, and E. coli bacteria were not detected in any sample.

\section{References Cited}

American Public Health Association, 1998, Standard methods for the examination of water and wastewater (20th ed.): Washington, D.C., American Public Health Association, American Water Works Association, and Water Environment Federation [variously paged].

ASTM International, 2006, D5072-98(2006), Standard test method for radon in drinking water: ASTM International, accessed December 28, 2006, at http://www.astm.org.

Butch, G.K., Murray, P.M., Hebert, G.J., and Weigel, J.F., 2003, Water resources data, New York, water year 2002: U.S. Geological Survey Water-Data Report NY-02-1, p. 502-520.

Cadwell, D.H., 1991, Surficial geologic map of New York: New York State Museum Map and Chart Series no. 40, Lower Hudson sheet, scale 1:250,000.

Childress, C.J.O., Foreman, W.T., Connor, B.F., and Maloney, T.J., 1999, New reporting procedures based on long-term method detection levels and some considerations for interpretations of water-quality data provided by the U.S. Geological Survey National Water Quality Laboratory: U.S. Geological Survey Open-File Report 99-193, 19 p.

Connor, B.F., Rose, D.L., Noriega, M.C., Murtagh, L.K., and Abney, S.R., 1998, Methods of analysis by the U.S. Geological Survey National Water Quality Laboratory-Determination of 86 volatile organic compounds in water by gas chromatography/mass spectrometry, including detections less than reporting limits: U.S. Geological Survey Open-File Report 97-829, 78 p.

Eckhardt, D.A., Reddy, J.E., and Shaw, S.B., 2009, Groundwater quality in central New York, 2007: U.S. Geological Survey Open-File Report 2009-1257, 40 p., at http://pubs.usgs.gov/of/2009/1257/.

Eckhardt, D.A., Reddy, J.E., and Tamulonis, K.L., 2007, Ground-water quality in the Genesee River Basin, New York, 2005-06: U.S. Geological Survey Open-File Report 2007-1093, 26 p., at http://pubs.usgs.gov/of/2007/1093/.

Eckhardt, D.A., Reddy, J.E., and Tamulonis, K.L., 2008, Ground-water quality in western New York, 2006: U.S. Geological Survey Open-File Report 2008-1140, 36 p., at http://pubs.usgs.gov/of/2008/1140/.

Fisher, D.W., Isachsen, Y.W., and Rickard, L.V., 1970, Geologic map of New York State: New York State Museum Map and Chart Series no. 15, Lower Hudson sheet, scale 1:250,000.

Fishman, M.J., ed., 1993, Methods of analysis by the U.S. Geological Survey National Water Quality Laboratory-Determination of inorganic and organic constituents in water and fluvial sediments: U.S. Geological Survey Open-File Report 93-125, 217 p.

Furlong, E.T., Anderson, B.D., Werner, S.L., Soliven, P.P., Coffey, L.J., and Burkhardt, M.R., 2001, Methods of analysis by the U.S. Geological Survey National Water Quality Laboratory-Determination of pesticides in water by graphitized carbon-based solid-phase extraction and high-performance liquid chromatography/mass spectrometry: U.S. Geological Survey Water-Resources Investigations Report 01-4134, $73 \mathrm{p}$.

Garbarino, J.R., and Damrau, D.L., 2001, Methods of analysis by the U.S. Geological Survey National Water Quality Laboratory-Determination of organic plus inorganic mercury in filtered and unfiltered natural water with cold vapor-atomic fluorescence spectrometry: U.S. Geological Survey WaterResources Investigations Report 01-4132, 16 p. 
Garbarino, J.R., Kanagy, L.K., and Cree, M.E., 2006, Determination of elements in natural-water, biota, sediment and soil samples using collision/reaction cell inductively coupled plasma-mass spectrometry: U.S. Geological Survey Techniques and Methods, book 5, chap. B1, 88 p.

Garbarino, J.R., and Struzeski, T.M., 1998, Methods of analysis by the U.S. Geological Survey National Water Quality Laboratory-Determination of elements in whole-water digests using inductively coupled plasma-optical emission spectrometry and inductively coupled plasma-mass spectrometry: U.S. Geological Survey Open-File Report 98-165, 101 p.

Giese, G.L., and Hobba, W.A, 1970, Water resources of the Champlain-Upper Hudson basins in New York State: Albany, NY, New York State Office of Planning Coordination, 153 p.

Hem, J.D., 1985, Study and interpretation of the chemical characteristics of natural water (3d ed.): U.S. Geological Survey Water-Supply Paper 2254, 264 p.

Hetcher-Aguila, K.K., 2005, Ground-water quality in the Chemung River Basin, New York, 2003: U.S. Geological Survey Open-File Report 2004-1329, 19 p., at http://ny.water.usgs.gov/pubs/of/of041329/. Hetcher-Aguila, K.K., and Eckhardt, D.A., 2006, Ground-water quality in the upper Susquehanna River Basin, New York, 2004: U.S. Geological Survey Open-File Report 2006-1161, 21 p., at http://pubs.usgs.gov/of/2006/1161/.

Hoffman, G.L., Fishman, M.J., and Garbarino, J.R., 1996, Methods of analysis by the U.S. Geological Survey National Water Quality Laboratory-In-bottle acid digestion of whole-water samples: U.S. Geological Survey Open-File Report 96-225, 28 p.

Isachsen, Y.W., Landing, E., Lauber, J.M., Rickard, L.V., and Rogers, W.B., eds., 2000, Geology of New York-A simplified account (2d ed.): Albany, NY, New York State Museum/Geological Survey, 294 p. New York State Department of Health, 2007, New York State Health Department public water systems regulations: Albany, NY [variously paged], accessed March 25, 2009, at http://www.health.state.ny.us/environmental/water/drinking/part5/tables.htm.

Nystrom, E.A., 2006, Ground-water quality in the Lake Champlain Basin, New York, 2004: U.S. Geological Survey Open-File Report 2006-1088, 22 p., at http://pubs.usgs.gov/of/2006/1088/.

Nystrom, E.A., 2007a, Ground-water quality in the St. Lawrence River Basin, New York, 2005-06: U.S. Geological Survey Open-File Report 2007-1066, 33 p., at http://pubs.usgs.gov/of/2007/1066/.

Nystrom, E.A., 2007b, Ground-water quality in the Delaware River Basin, New York, 2001 \& 2005-06: U.S. Geological Survey Open-File Report 2007-1098, 36 p., at http://pubs.usgs.gov/of/2007/1098/. Nystrom, E.A., 2008, Ground-water quality in the Mohawk River Basin, New York, 2006: U.S. Geological Survey Open-File Report 2008-1086, 33 p., at http://pubs.usgs.gov/of/2008/1086/.

Nystrom, E.A., 2009, Groundwater quality in the Upper Hudson River Basin, New York, 2007: U.S. Geological Survey Open-File Report 2009-1240, 37 p., at http://pubs.usgs.gov/of/2009/1240/.

Nystrom, E.A., 2010, Groundwater quality in the Lower Hudson River Basin, New York, 2008: U.S. Geological Survey Open-File Report 2010-1197, 39 p., at http://pubs.usgs.gov/of/2010/1197/.

Patton, C.J., and Truitt, E.P., 2000, Methods of analysis by the U.S. Geological Survey National Water Quality Laboratory_Determination of ammonium plus organic nitrogen by a Kjeldahl digestion method and an automated photometric finish that includes digest cleanup by gas diffusion: U.S. Geological Survey Open-File Report 00-170, 31 p.

Risen, A.J., and Reddy, J.E., 2011a, Groundwater quality in the Chemung River Basin, 2008: U.S. Geological Survey Open-File Report 2011-1112, 25 p., at http://pubs.usgs.gov/of/2011/1112/.

Risen, A.J., and Reddy, J.E., 2011b, Groundwater Quality in the Eastern Lake Ontario Basin New York, 2008: U.S. Geological Survey Open-File Report 32 p., at http://pubs.usgs.gov/of/2011/1074/.

Sandstrom, M.W., Stroppel, M.E., Foreman, W.T., and Schroeder, M.P., 2001, Methods of analysis by the U.S. Geological Survey National Water Quality Laboratory-Determination of moderate-use pesticides and selected degradates in water by C-18 solid-phase extraction and gas chromatography/mass spectrometry: U.S. Geological Survey Water-Resources Investigations Report 01-4098, 70 p. 
Struzeski, T.M., DeGiacomo, W.J., and Zayhowski, E.J., 1996, Methods of analysis by the U.S. Geological Survey National Water Quality Laboratory-Determination of dissolved aluminum and boron in water by inductively coupled plasma-atomic emission spectrometry: U.S. Geological Survey Open-File Report 96-149, 17 p.

U.S. Environmental Protection Agency, 1980, Prescribed procedures for measurement of radioactivity in drinking water: EPA 600/4-80-032, at http://www.epa.gov/osw/hazard/testmethods/sw846/pdfs/9060a.pdf.

U.S. Environmental Protection Agency, 1997, Guidelines for preparation of the comprehensive state water quality assessments (305(b) Reports) and electronic updates: Washington, D.C., U.S. Environmental Protection Agency, Office of Water, EPA 841-B-97-002A and EPA 841-B-97-002B, PL95-217, 271 p.

U.S. Environmental Protection Agency, 1999, Proposed radon in drinking water rule: Washington, D.C., U.S. Environmental Protection Agency, Office of Water, EPA 815-F-99-006, 6 p.

U.S. Environmental Protection Agency, 2009, National primary drinking water standards and national secondary drinking water standards: Washington, D.C., U.S. Environmental Protection Agency, Office of Water, EPA 816-F-09-0004, 6 p., at http://www.epa.gov/safewater/consumer/pdf/mcl.pdf.

U.S. Geological Survey, variously dated, National field manual for the collection of water-quality data: U.S. Geological Survey Techniques of Water-Resource Investigations, book 9, chaps. A1-A9 [variously paged].

U.S. Geological Survey, 2006, Collection of water samples (ver. 2.0): U.S. Geological Survey Techniques of Water-Resources Investigations, book 9, chap. A4, September, accessed March 4, 2010, at http://pubs.water.usgs.gov/twri9A4/.

Vogelmann, J.E., Howard, S.M., Yang, L., Larson, C.R., Wylie, B.K., and Van Driel, J.N., 2001, Completion of the 1990's National Land Cover Data Set for the conterminous United States: Photogrammetric Engineering and Remote Sensing, v. 67, p. 650-662.

Wershaw, R.L., Fishman, M.J., Grabbe, R.R., and Lowe, L.E., 1987, Methods for the determination of organic substances in water and fluvial sediments, U.S. Geological Survey Techniques of WaterResources Investigations, book 5, chap. A3, 80 p.

Wilde, F.D., ed., 2004, Cleaning of equipment for water sampling (ver. 2.0): U.S. Geological Survey Techniques of Water-Resources Investigations, book 9, chap. A3, April, accessed March 4, 2010, at http://pubs.water.usgs.gov/twri9A3/.

Wilde, F.D., Radtke, D.B., Gibs, Jacob, and Iwatsubo, R.T., eds., 2004 with updates through 2009, Processing of water samples (version 2.2): U.S. Geological Survey Techniques of Water-Resources Investigations, book 9, chap. A5, April, accessed March 4, 2010, at http://pubs.water.usgs.gov/twri9A5/. Zaugg, S.D., Sandstrom, M.W., Smith, S.G., and Fehlberg, K.M., 1995, Methods of analysis by the U.S. Geological Survey National Water Quality Laboratory-Determination of pesticides in water by C-18 solid-phase extraction and capillary-column gas chromatography/mass spectrometry with selected-ion monitoring: U.S. Geological Survey Open-File Report 95-181, 60 p. 


\section{Appendix 1: Results of Water-Sample Analyses}

The following tables summarize results of the chemical analyses of the 20 samples collected in the Lake Champlain Basin of eastern New York from August through November 2009.

1-1. Constituents that were not detected in groundwater samples collected in the Lake Champlain Basin, New York, 2009.

1-2. Physiochemical properties of groundwater samples collected in the Lake Champlain Basin, New York, 2009

1-3. Concentrations of major ions in groundwater samples collected in the Lake Champlain Basin, New York, 2009.

1-4. Concentrations of nutrients and organic carbon in groundwater samples collected in the Lake Champlain Basin, New York, 2009.

1-5. Concentrations of trace elements in groundwater samples collected in the Lake Champlain Basin, New York, 2009.

1-6. Concentrations of pesticides and pesticide degradates detected in groundwater samples collected in the Lake Champlain Basin, New York, 2009.

1-7. Concentrations of volatile organic compounds detected in groundwater samples collected in the Lake Champlain Basin, New York, 2009.

1-8. Activities of radionuclides in groundwater samples from the Lake Champlain Basin, New York, 2009.......... 35

1-9. Bacteria in groundwater samples collected in the Lake Champlain Basin, New York, 2009. 
Table 1-1. Constituents that were not detected in groundwater samples collected in the Lake Champlain Basin, New York, 2009.

[NWIS, National Water Information System; WY, water year, the 12-month period from October 1 through September 30 of the following year. The water year is designated by the calendar year in which it ends.]

\begin{tabular}{|c|c|c|c|}
\hline \multirow{2}{*}{$\begin{array}{l}\text { U.S. Geological } \\
\text { Survey NWIS } \\
\text { parameter code }\end{array}$} & \multirow[b]{2}{*}{ Constituent } & \multicolumn{2}{|c|}{ Laboratory reporting level } \\
\hline & & WY09 & WY10 \\
\hline \multicolumn{4}{|c|}{ Trace elements in unfiltered water, micrograms per liter } \\
\hline 01097 & Antimony & 0.4 & 0.4 \\
\hline 71900 & Mercury & .010 & .010 \\
\hline 01059 & Thallium & .12 & .12 \\
\hline \multicolumn{4}{|c|}{ Pesticides in filtered water, micrograms per liter } \\
\hline 82660 & 2,6-Diethylaniline & .006 & .006 \\
\hline 49260 & Acetochlor & .010 & .010 \\
\hline 46342 & Alachlor & .008 & .008 \\
\hline 34253 & alpha-HCH & .008 & .004 \\
\hline 82686 & Azinphos-methyl & .120 & .120 \\
\hline 82673 & Benfluralin & .014 & .014 \\
\hline 04028 & Butylate & .002 & .004 \\
\hline 82680 & Carbaryl & .200 & .060 \\
\hline 82674 & Carbofuran & .060 & .060 \\
\hline 38933 & Chlorpyrifos & .010 & .010 \\
\hline 82687 & cis-Permethrin & .014 & .014 \\
\hline 04041 & Cyanazine & .040 & .022 \\
\hline 82682 & DCPA & .006 & .008 \\
\hline 39572 & Diazinon & .005 & .005 \\
\hline 39381 & Dieldrin & .009 & .009 \\
\hline 82668 & EPTC & .002 & .002 \\
\hline 82663 & Ethalfluralin & .009 & .006 \\
\hline 82672 & Ethoprop & .016 & .016 \\
\hline 62169 & Desulfinylfipronil amide & .029 & .029 \\
\hline 62167 & Fipronil sulfide & .013 & .013 \\
\hline 62168 & Fipronil sulfone & .024 & .024 \\
\hline 04095 & Fonofos & .010 & .004 \\
\hline 39341 & Lindane & .014 & .004 \\
\hline 82666 & Linuron & .060 & .060 \\
\hline 39532 & Malathion & .020 & .016 \\
\hline 82667 & Methyl parathion & .008 & .008 \\
\hline 39415 & Metolachlor & .014 & .014 \\
\hline 82630 & Metribuzin & .016 & .012 \\
\hline 82671 & Molinate & .002 & .003 \\
\hline 82684 & Napropamide & .018 & .008 \\
\hline 34653 & $p, p^{\prime}-\mathrm{DDE}$ & .003 & .002 \\
\hline 39542 & Parathion & .020 & .020 \\
\hline 82669 & Pebulate & .016 & .016 \\
\hline 82683 & Pendimethalin & .012 & .012 \\
\hline
\end{tabular}


Table 1-1. Constituents that were not detected in groundwater samples collected in the Lake Champlain Basin, New York, 2009.-Continued

[NWIS, National Water Information System; WY, water year, the 12-month period from October 1 through September 30 of the following year. The water year is designated by the calendar year in which it ends.]

\begin{tabular}{|c|c|c|c|}
\hline \multirow{2}{*}{$\begin{array}{l}\text { U.S. Geological } \\
\text { Survey NWIS } \\
\text { parameter code }\end{array}$} & \multirow[b]{2}{*}{ Constituent } & \multicolumn{2}{|c|}{ Laboratory reporting level } \\
\hline & & WY09 & WY10 \\
\hline \multicolumn{4}{|c|}{ Pesticides in filtered water, micrograms per liter } \\
\hline 82664 & Phorate & 0.020 & 0.020 \\
\hline 82676 & Propyzamide & .004 & .004 \\
\hline 04024 & Propachlor & .012 & .006 \\
\hline 82679 & Propanil & .014 & .010 \\
\hline 82685 & Propargite & .02 & .02 \\
\hline 04035 & Simazine & .010 & .006 \\
\hline 82670 & Tebuthiuron & .02 & .03 \\
\hline 82665 & Terbacil & .040 & .024 \\
\hline 82675 & Terbufos & .02 & .02 \\
\hline 82681 & Thiobencarb & .016 & 016 \\
\hline 82678 & Triallate & .006 & .006 \\
\hline 82661 & Trifluralin & .012 & .018 \\
\hline \multicolumn{4}{|c|}{ Volatile organic compounds in unfiltered water, micrograms per liter } \\
\hline 34506 & 1,1,1-Trichloroethane & .1 & .1 \\
\hline 77652 & 1,1,2-Trichloro-1,2,2-trifluoroethane & .1 & .1 \\
\hline 34496 & 1,1-Dichloroethane & .1 & .1 \\
\hline 34536 & 1,2-Dichlorobenzene & .1 & .1 \\
\hline 32103 & 1,2-Dichloroethane & .2 & .2 \\
\hline 34541 & 1,2-Dichloropropane & .1 & .1 \\
\hline 34566 & 1,3-Dichlorobenzene & .1 & .1 \\
\hline 34571 & 1,4-Dichlorobenzene & .1 & .1 \\
\hline 34030 & Benzene & .1 & .1 \\
\hline 34301 & Chlorobenzene & .1 & .1 \\
\hline 77093 & cis-1,2-Dichloroethene & .1 & .1 \\
\hline 34668 & Dichlorodifluoromethane & .2 & .2 \\
\hline 34423 & Dichloromethane & .2 & .2 \\
\hline 81576 & Diethyl ether & .2 & .2 \\
\hline 81577 & Diisopropyl ether & .2 & .2 \\
\hline 34371 & Ethylbenzene & .1 & .1 \\
\hline 50005 & Methyl tert-pentyl ether & .2 & .2 \\
\hline 85795 & $m$-Xylene plus $p$-xylene & .2 & .2 \\
\hline 77135 & $o$-Xylene & .1 & .1 \\
\hline 77128 & Styrene & .1 & .1 \\
\hline 50004 & tert-Butyl ethyl ether & .1 & .1 \\
\hline 34475 & Tetrachloroethene & .1 & .1 \\
\hline 32102 & Tetrachloromethane & .2 & .2 \\
\hline 34010 & Toluene & .1 & .1 \\
\hline 34546 & trans-1,2-Dichloroethene & .1 & .1 \\
\hline 39180 & Trichloroethene & .1 & .1 \\
\hline 34488 & Trichlorofluoromethane & .2 & .2 \\
\hline 39175 & Vinyl chloride & .2 & .2 \\
\hline
\end{tabular}


Table 1-2. Physiochemical properties of groundwater samples collected in the Lake Champlain Basin, New York, 2009.

[mg/L, milligrams per liter; $\mu \mathrm{S} / \mathrm{cm}$, microsiemens per centimeter at 25 degrees Celsius; (00080), U.S. Geological Survey

National Water Information System parameter code; <, less than. Bold values exceed one or more drinking-water standards. Well locations are shown in figure 2.]

\begin{tabular}{|c|c|c|c|c|c|}
\hline $\begin{array}{c}\text { Well } \\
\text { number }^{1}\end{array}$ & $\begin{array}{c}\text { Color, } \\
\text { platinum-cobalt } \\
\text { units } \\
(00080) \\
\end{array}$ & $\begin{array}{c}\text { Carbon } \\
\text { dioxide, } \\
\text { mg/L } \\
(00405)\end{array}$ & $\begin{array}{c}\text { Dissolved } \\
\text { oxygen, } \\
\text { mg/L } \\
(00300) \\
\end{array}$ & $\begin{array}{c}\mathrm{pH}, \\
\text { standard } \\
\text { units } \\
(00400) \\
\end{array}$ & $\begin{array}{c}\text { Specific } \\
\text { conductance, } \\
\mu S / \mathrm{cm} \\
(00095)\end{array}$ \\
\hline \multicolumn{6}{|c|}{ Sand and gravel wells } \\
\hline CL151 & 2 & 2.5 & 11.0 & 7.4 & 353 \\
\hline CL1500 & $<1$ & 2.0 & 5.1 & 7.7 & 94 \\
\hline EX155 & $<1$ & 8.7 & 5.4 & 7.0 & 95 \\
\hline EX535 & 2 & 11.8 & 1.6 & 7.0 & 482 \\
\hline EX589 & $<1$ & 1.1 & 9.7 & 7.7 & 115 \\
\hline EX1013 & 5 & .5 & 13.6 & 8.5 & 65 \\
\hline W534 & 2 & 11.5 & 3.3 & 6.8 & 422 \\
\hline W1066 & 2 & 3.8 & 8.6 & 7.5 & 403 \\
\hline \multicolumn{6}{|c|}{ Bedrock wells } \\
\hline CL149 & 20 & 16.2 & .3 & 7.2 & 1,250 \\
\hline CL154 & 5 & 11.9 & .2 & 6.7 & 1,220 \\
\hline CL665 & $<1$ & 2.6 & 1.5 & 7.0 & 274 \\
\hline EX169 & $<1$ & 5.1 & 7.2 & 7.5 & 241 \\
\hline EX378 & $<1$ & 19.5 & 2.1 & 6.6 & 531 \\
\hline EX664 & $<1$ & 1.4 & 1.8 & 7.2 & 221 \\
\hline W1145 & $<1$ & 40.9 & $<.1$ & 6.4 & 827 \\
\hline W1544 & 2 & 61.1 & 1.7 & 6.2 & 761 \\
\hline WR86 & $<1$ & 1.9 & 10.0 & 7.7 & 428 \\
\hline WR1326 & 2 & 26.0 & 3.8 & 5.9 & 139 \\
\hline WR1433 & $<1$ & 7.3 & .1 & 7.4 & 1,310 \\
\hline WR1671 & 5 & 8.0 & .6 & 6.7 & 427 \\
\hline
\end{tabular}

${ }^{1}$ CL, Clinton County; EX, Essex County; W, Washington County; WR, Warren County. 
Table 1-2. Physiochemical properties of groundwater samples collected in the Lake Champlain Basin, New York, 2009. - Continued

$[\mathrm{mg} / \mathrm{L}$, milligrams per liter; $\mu \mathrm{S} / \mathrm{cm}$, microsiemens per centimeter at 25 degrees Celsius; (00080), U.S. Geological Survey National Water Information System parameter code; <, less than. Bold values exceed one or more drinking-water standards. Well locations are shown in figure 2.]

\begin{tabular}{|c|c|c|c|c|c|}
\hline $\begin{array}{c}\text { Well } \\
\text { number }^{1}\end{array}$ & $\begin{array}{c}\text { Water } \\
\text { temperature, } \\
\text { degrees Celsius } \\
(00010) \\
\end{array}$ & $\begin{array}{c}\text { Argon, } \\
\text { unfiltered, } \\
\text { mg/L } \\
(82043) \\
\end{array}$ & $\begin{array}{c}\text { Dissolved } \\
\text { nitrogen gas, } \\
\text { unfiltered, } \\
\mathrm{mg} / \mathrm{L} \\
(00597) \\
\end{array}$ & $\begin{array}{c}\text { Hydrogen } \\
\text { sulfide odor } \\
(71875)\end{array}$ & $\begin{array}{c}\text { Methane, } \\
\text { unfiltered, } \\
\text { mg/L } \\
(76994)\end{array}$ \\
\hline \multicolumn{6}{|c|}{ Sand and gravel wells } \\
\hline CL151 & 8.5 & 0.80 & 22.95 & Absent & 0.000 \\
\hline CL1500 & 8.4 & .75 & 20.18 & Absent & .000 \\
\hline EX155 & 7.9 & .75 & 20.21 & Absent & .000 \\
\hline EX535 & 13.5 & .96 & 29.53 & Absent & .000 \\
\hline EX589 & 8.3 & .77 & 21.14 & Absent & .002 \\
\hline EX1013 & 8.8 & .81 & 22.69 & Absent & .000 \\
\hline W534 & 9.8 & .72 & 20.23 & Absent & .000 \\
\hline W1066 & 10.8 & .80 & 22.18 & Absent & .000 \\
\hline \multicolumn{6}{|c|}{ Bedrock wells } \\
\hline CL149 & 9.0 & .74 & 21.22 & Absent & .030 \\
\hline CL154 & 9.9 & .86 & 25.80 & Absent & .072 \\
\hline CL665 & 9.6 & .82 & 22.90 & Absent & .000 \\
\hline EX169 & 8.7 & .78 & 21.25 & Absent & .000 \\
\hline EX378 & 9.3 & .82 & 23.78 & Absent & .000 \\
\hline EX664 & 15.1 & .82 & 23.58 & Absent & .000 \\
\hline W1145 & 9.9 & .94 & 32.98 & Present & .006 \\
\hline W1544 & 10.2 & .76 & 21.32 & Absent & .000 \\
\hline WR86 & 8.7 & .81 & 23.30 & Absent & .000 \\
\hline WR1326 & 10.1 & .79 & 22.51 & Absent & .000 \\
\hline WR1433 & 14.3 & .80 & 22.30 & Absent & .002 \\
\hline WR1671 & 12.2 & .82 & 25.83 & Absent & .000 \\
\hline
\end{tabular}

${ }^{1}$ CL, Clinton County; EX, Essex County; W, Washington County; WR, Warren County. 
Table 1-3. Concentrations of major ions in groundwater samples collected in the Lake Champlain Basin, New York, 2009.

[mg/L, milligrams per liter; $\mathrm{CaCO}_{3}$, calcium carbonate; (00900), U.S. Geological Survey National Water Information System parameter code. Bold values exceed one or more drinking-water standards. Well locations are shown in figure 2.]

\begin{tabular}{|c|c|c|c|c|c|c|c|}
\hline $\begin{array}{c}\text { Well } \\
\text { number }^{1}\end{array}$ & $\begin{array}{l}\text { Hardness, } \\
\text { filtered, } \\
\text { mg/L as } \\
\mathrm{CaCO}_{3} \\
(00900)\end{array}$ & $\begin{array}{c}\text { Calcium, } \\
\text { filtered, } \\
\text { mg/L } \\
(00915)\end{array}$ & $\begin{array}{c}\text { Magnesium, } \\
\text { filtered, } \\
\text { mg/L } \\
(00925)\end{array}$ & $\begin{array}{c}\text { Potassium, } \\
\text { filtered, } \\
\text { mg/L } \\
(00935)\end{array}$ & $\begin{array}{c}\text { Sodium, } \\
\text { filtered, } \\
\text { mg/L } \\
(00930)\end{array}$ & $\begin{array}{c}\text { Acid } \\
\text { neutralizing } \\
\text { capacity, } \\
\text { unfiltered, } \\
\mathrm{mg}^{\prime} \mathrm{L} \text { as } \\
\mathrm{CaCO}_{3} \\
(90410) \\
\end{array}$ & $\begin{array}{l}\text { Alkalinity, } \\
\text { filtered, } \\
\text { incremental } \\
\text { titration, } \\
\text { field, } \\
\text { mg/L as } \\
\mathrm{CaCO}_{3} \\
(39086) \\
\end{array}$ \\
\hline \multicolumn{8}{|c|}{ Sand and gravel wells } \\
\hline CL151 & 170 & 44.1 & 13.9 & 0.95 & 6.13 & 121 & 115 \\
\hline CL1500 & 73 & 19.4 & 5.91 & .83 & 2.66 & 76 & 62 \\
\hline EX155 & 31 & 8.68 & 2.37 & .54 & 2.25 & 28 & 26 \\
\hline EX535 & 250 & 57.1 & 27.0 & .78 & 3.61 & 194 & 228 \\
\hline EX589 & 81 & 22.4 & 6.07 & .43 & 3.27 & 79 & 77 \\
\hline EX1013 & 40 & 11.4 & 2.83 & .33 & 1.79 & 38 & 30 \\
\hline W534 & 210 & 55.9 & 16.6 & .79 & 3.72 & 190 & 170 \\
\hline W1066 & 190 & 50.9 & 14.2 & .96 & 6.55 & 148 & 145 \\
\hline \multicolumn{8}{|c|}{ Bedrock wells } \\
\hline CL149 & 320 & 69.2 & 35.0 & 8.85 & 125 & 264 & 230 \\
\hline CL154 & 240 & 60.6 & 21.8 & 11.0 & 148 & 262 & 228 \\
\hline CL665 & 130 & 29.0 & 13.7 & 2.08 & 3.71 & 126 & 111 \\
\hline EX169 & 86 & 26.6 & 4.73 & .83 & 9.94 & 72 & 70 \\
\hline EX378 & 280 & 60.1 & 30.4 & .69 & 19.4 & 273 & 243 \\
\hline EX664 & 90 & 30.1 & 3.67 & .57 & 5.23 & 80 & 64 \\
\hline W1145 & 440 & 84.7 & 56.0 & 2.44 & 20.1 & 383 & 340 \\
\hline W1544 & 360 & 135 & 5.53 & .24 & 19.1 & 211 & 301 \\
\hline WR86 & 120 & 38.9 & 4.87 & .94 & 33.8 & 69 & 56 \\
\hline WR1326 & 55 & 15.4 & 4.00 & 1.03 & 2.10 & 51 & 44 \\
\hline WR1433 & 490 & 149 & 28.4 & 1.66 & 67.9 & 148 & 151 \\
\hline WR1671 & 190 & 46.9 & 18.4 & 1.37 & 7.31 & 166 & 158 \\
\hline
\end{tabular}

${ }^{1}$ CL, Clinton County; EX, Essex County; W, Washington County; WR, Warren County. 
Table 1-3. Concentrations of major ions in groundwater samples collected in the Lake Champlain Basin, New York, 2009.-Continued

[mg/L, milligrams per liter; $\mathrm{CaCO}_{3}$, calcium carbonate; (00900), U.S. Geological Survey National Water Information System parameter code; ${ }^{\circ} \mathrm{C}$, degrees Celsius; <, less than; E, estimated concentration. Bold values exceed one or more drinking-water standards. Well locations are shown in figure 2.]

\begin{tabular}{|c|c|c|c|c|c|c|}
\hline $\begin{array}{c}\text { Well } \\
\text { number }\end{array}$ & $\begin{array}{l}\text { Bicarbonate, } \\
\text { filtered, } \\
\text { incremental } \\
\text { titration, } \\
\text { field, } \\
\text { mg/L } \\
(00453)\end{array}$ & $\begin{array}{c}\text { Chloride, } \\
\text { filtered, } \\
\text { mg/L } \\
(00940)\end{array}$ & $\begin{array}{c}\text { Fluoride, } \\
\text { filtered, } \\
\text { mg/L } \\
(00950)\end{array}$ & $\begin{array}{c}\text { Silica, } \\
\text { filtered, } \\
\mathrm{mg} / \mathrm{L} \\
(00955)\end{array}$ & $\begin{array}{c}\text { Sulfate, } \\
\text { filtered, } \\
\mathrm{mg} / \mathrm{L} \\
(00945)\end{array}$ & $\begin{array}{c}\text { Dissolved } \\
\text { solids, } \\
\text { dried at } 180^{\circ} \mathrm{C} \\
\text { filtered, } \\
\mathrm{mg} / \mathrm{L} \\
(70300)\end{array}$ \\
\hline \multicolumn{7}{|c|}{ Sand and gravel wells } \\
\hline CL151 & E 139 & 26.5 & E 0.06 & 12.6 & 8.54 & 196 \\
\hline CL1500 & E 75 & .43 & .10 & 17.4 & 6.14 & 101 \\
\hline EX155 & E 32 & 1.67 & $<.08$ & 18.4 & 7.90 & 65 \\
\hline EX535 & 277 & .74 & E .07 & 15.4 & 29.6 & 268 \\
\hline EX589 & Е 93 & 1.31 & E.06 & 19.0 & 10.8 & 100 \\
\hline EX1013 & E 36 & 1.15 & $<.08$ & 15.0 & 5.96 & 49 \\
\hline W534 & 207 & 6.46 & E .08 & 10.5 & 23.2 & 236 \\
\hline W1066 & 176 & 18.1 & E.05 & 9.52 & 17.6 & 211 \\
\hline \multicolumn{7}{|c|}{ Bedrock wells } \\
\hline CL149 & 280 & 193 & .15 & 8.68 & 89.4 & 700 \\
\hline CL154 & 278 & 210 & .22 & 6.96 & 44.2 & 677 \\
\hline CL665 & 134 & .97 & .49 & 10.8 & 13.1 & 144 \\
\hline EX169 & E 85 & 18.3 & E. .08 & 18.7 & 11.4 & 135 \\
\hline EX378 & 295 & 4.26 & .19 & 15.6 & 19.6 & 320 \\
\hline EX664 & E 77 & 1.03 & .80 & 8.61 & 24.4 & 132 \\
\hline W1145 & 413 & 6.86 & .13 & 16.2 & 74.7 & 501 \\
\hline W1544 & E 367 & 31.7 & Е .08 & 5.57 & 22.7 & 431 \\
\hline WR86 & 67 & 91.6 & .41 & 10.4 & 8.01 & 258 \\
\hline WR1326 & E 54 & .89 & Е .09 & 16.6 & 11.1 & 81 \\
\hline WR1433 & 183 & 170 & .36 & 17.4 & 239 & 779 \\
\hline WR1671 & 192 & 21.8 & .25 & 11.1 & 17.6 & 226 \\
\hline
\end{tabular}

${ }^{1}$ CL, Clinton County; EX, Essex County; W, Washington County; WR, Warren County. 
Table 1-4. Concentrations of nutrients and organic carbon in groundwater samples collected in the Lake Champlain Basin, New York, 2009.

[N, nitrogen; P, phosphorus; mg/L, milligrams per liter; (00623), U.S. Geological Survey National Water Information System parameter code; < less than; E, estimated concentration. Well locations are shown in figure 2.]

\begin{tabular}{|c|c|c|c|c|c|c|}
\hline $\begin{array}{c}\text { Well } \\
\text { number }^{1}\end{array}$ & $\begin{array}{l}\text { Ammonia plus } \\
\text { organic- } \mathrm{N} \text {, } \\
\text { filtered, } \\
\text { mg/L as } \mathrm{N} \\
(00623)\end{array}$ & $\begin{array}{l}\text { Ammonia, } \\
\text { filtered, } \\
\text { mg/L as N } \\
(00608)\end{array}$ & $\begin{array}{l}\text { Nitrate plus } \\
\text { nitrite, } \\
\text { filtered, } \\
\text { mg/L as N } \\
\text { (00631) }\end{array}$ & $\begin{array}{l}\text { Nitrite, } \\
\text { filtered, } \\
\text { mg/L as N } \\
(00613)\end{array}$ & $\begin{array}{c}\text { Ortho- } \\
\text { phosphate, } \\
\text { filtered, } \\
\text { mg/L as P } \\
\text { (00671) }\end{array}$ & $\begin{array}{c}\text { Organic } \\
\text { carbon, } \\
\text { unfiltered, } \\
\text { mg/L } \\
(00680)\end{array}$ \\
\hline \multicolumn{7}{|c|}{ Sand and gravel wells } \\
\hline CL151 & $<0.10$ & $<0.020$ & 1.67 & $<0.002$ & 0.019 & E 0.4 \\
\hline CL1500 & $<.10$ & $<.020$ & .19 & $<.002$ & .035 & $<.6$ \\
\hline EX155 & $<.10$ & E .014 & .15 & $<.002$ & .009 & .7 \\
\hline EX535 & $<.10$ & $<.020$ & $<.04$ & $<.002$ & .009 & E. 5 \\
\hline EX589 & $<.10$ & $<.020$ & .12 & $<.002$ & .050 & .6 \\
\hline EX1013 & $<.10$ & $<.020$ & .17 & $<.002$ & .039 & $<.6$ \\
\hline W534 & $<.10$ & $<.020$ & .23 & $<.002$ & .009 & E. 5 \\
\hline W1066 & $<.10$ & $<.020$ & 3.79 & $<.002$ & E .004 & .8 \\
\hline \multicolumn{7}{|c|}{ Bedrock wells } \\
\hline CL149 & $<.10$ & $<.020$ & $<.04$ & $<.002$ & .086 & 1.3 \\
\hline CL154 & $<.10$ & $<.020$ & $<.04$ & $<.002$ & E .005 & E 1.3 \\
\hline CL665 & $<.10$ & $<.020$ & .29 & $<.002$ & .010 & $<.6$ \\
\hline EX169 & $<.10$ & $<.020$ & .37 & $<.002$ & .020 & 1.5 \\
\hline EX378 & E .07 & $<.020$ & 2.33 & $<.002$ & E .007 & .7 \\
\hline EX664 & $<.10$ & $<.020$ & E.03 & $<.002$ & E .005 & $<.6$ \\
\hline W1145 & .53 & .474 & $<.04$ & $<.002$ & .010 & E.3 \\
\hline W1544 & E .07 & $<.020$ & .68 & $<.002$ & E .006 & 1.1 \\
\hline WR86 & $<.10$ & $<.020$ & .06 & $<.002$ & Е .005 & E.4 \\
\hline WR1326 & $<.10$ & $<.020$ & .15 & $<.002$ & .010 & .6 \\
\hline WR1433 & $<.10$ & $<.020$ & E. 02 & $<.002$ & E .005 & .7 \\
\hline WR1671 & .26 & .023 & .06 & .002 & .011 & $<.6$ \\
\hline
\end{tabular}

\footnotetext{
${ }^{1}$ CL, Clinton County; EX, Essex County; W, Washington County; WR, Warren County.
} 
Table 1-5. Concentrations of trace elements in groundwater samples collected in the Lake Champlain Basin, New York, 2009.

[ $\mu \mathrm{g} / \mathrm{L}$, micrograms per liter; (01105), U.S. Geological Survey National Water Information System parameter code; <, less than; E, estimated concentration. Well locations are shown in figure 2.]

\begin{tabular}{|c|c|c|c|c|c|c|c|}
\hline $\begin{array}{c}\text { Well } \\
\text { number1 }\end{array}$ & $\begin{array}{c}\text { Aluminum, } \\
\text { unfiltered, } \\
\mu \mathrm{g} / \mathrm{L} \\
(01105)\end{array}$ & $\begin{array}{c}\text { Arsenic, } \\
\text { unfiltered, } \\
\mu \mathrm{g} / \mathrm{L} \\
(01002)\end{array}$ & $\begin{array}{c}\text { Barium, } \\
\text { unfiltered, } \\
\mu \mathrm{g} / \mathrm{L} \\
(01007)\end{array}$ & $\begin{array}{c}\text { Beryllium, } \\
\text { unfiltered, } \\
\mu \mathrm{g} / \mathrm{L} \\
(01012)\end{array}$ & $\begin{array}{c}\text { Boron, } \\
\text { filtered, } \\
\mu \mathrm{g} / \mathrm{L} \\
(01020)\end{array}$ & $\begin{array}{c}\text { Cadmium, } \\
\text { unfiltered, } \\
\mu \mathrm{g} / \mathrm{L} \\
(01027)\end{array}$ & $\begin{array}{c}\text { Chromium } \\
\text { unfiltered, } \\
\mu \mathrm{g} / \mathrm{L} \\
(01034)\end{array}$ \\
\hline \multicolumn{8}{|c|}{ Sand and gravel wells } \\
\hline CL151 & $<6$ & 0.67 & 12.2 & $<0.02$ & 2.8 & $<0.06$ & 1.3 \\
\hline CL1500 & $<6$ & .34 & 9.0 & $<.02$ & 4.1 & $<.06$ & .47 \\
\hline EX155 & $<6$ & .20 & 1.5 & $<.02$ & 4.3 & $<.06$ & $<.40$ \\
\hline EX535 & 9 & .92 & 11.8 & $<.02$ & E 1.9 & $<.06$ & $<.40$ \\
\hline EX589 & E 4 & .89 & 2.8 & $<.02$ & 8.7 & $<.06$ & .51 \\
\hline EX1013 & E 4 & .50 & 2.2 & $<.04$ & E 1.5 & $<.04$ & .87 \\
\hline W534 & $<6$ & .97 & 13.8 & $<.02$ & 7.9 & $<.06$ & $<.40$ \\
\hline W1066 & $<6$ & .31 & 14.2 & $<.02$ & 8.2 & $<.06$ & E. 24 \\
\hline \multicolumn{8}{|c|}{ Bedrock wells } \\
\hline CL149 & $<6$ & 1.2 & 86.9 & $<.04$ & 110 & $<.04$ & E .27 \\
\hline CL154 & $<6$ & .87 & 103 & E .01 & 98 & $<.06$ & $<.40$ \\
\hline CL665 & $<6$ & .49 & 120 & $<.04$ & 14 & $<.04$ & .54 \\
\hline EX169 & $<6$ & .44 & 14.9 & $<.02$ & 10 & $<.06$ & E .39 \\
\hline EX378 & $<6$ & .56 & $<.6$ & $<.04$ & 16 & $<.04$ & .50 \\
\hline EX664 & 12 & .29 & 25.0 & .03 & 26 & $<.06$ & $<.40$ \\
\hline W1145 & $<6$ & 1.6 & 53.7 & $<.04$ & 33 & $<.04$ & $<.42$ \\
\hline W1544 & 8 & 1.9 & 30.5 & $<.02$ & 4.3 & E.03 & $<.40$ \\
\hline WR86 & E 5 & .30 & 3.4 & $<.04$ & 5.9 & $<.04$ & $<.42$ \\
\hline WR1326 & E 3 & .26 & 44.7 & $<.02$ & 7.0 & $<.06$ & E.23 \\
\hline WR1433 & $<6$ & 1.6 & 29.1 & $<.02$ & 184 & $<.06$ & $<.40$ \\
\hline WR1671 & E 4 & 5.4 & 43.7 & $<.02$ & 16 & $<.06$ & $<.40$ \\
\hline
\end{tabular}

${ }^{1}$ CL, Clinton County; EX, Essex County; W, Washington County; WR, Warren County. 
Table 1-5. Concentrations of trace elements in groundwater samples collected in the Lake Champlain Basin, New York, 2009.-Continued

[ $\mu \mathrm{g} / \mathrm{L}$, micrograms per liter; (01105), U.S. Geological Survey National Water Information System parameter code; <, less than; E, estimated concentration. Bold values exceed one or more drinking water standards. Well locations are shown in figure 2.]

\begin{tabular}{|c|c|c|c|c|c|c|c|c|}
\hline $\begin{array}{c}\text { Well } \\
\text { number }\end{array}$ & $\begin{array}{c}\text { Cobalt, } \\
\text { unfiltered, } \\
\mu \mathrm{g} / \mathrm{L} \\
(01037)\end{array}$ & $\begin{array}{c}\text { Copper, } \\
\text { unfiltered, } \\
\mu \mathrm{g} / \mathrm{L} \\
(01042)\end{array}$ & $\begin{array}{c}\text { Iron, } \\
\text { filtered, } \\
\mu \mathrm{g} / \mathrm{L} \\
(01046)\end{array}$ & $\begin{array}{c}\text { Iron, } \\
\text { unfiltered, } \\
\mu \mathrm{g} / \mathrm{L} \\
(01045)\end{array}$ & $\begin{array}{c}\text { Lead, } \\
\text { unfiltered, } \\
\mu \mathrm{g} / \mathrm{L} \\
(01051)\end{array}$ & $\begin{array}{c}\text { Lithium, } \\
\text { unfiltered, } \\
\mu \mathrm{g} / \mathrm{L} \\
(\mathbf{0 1 1 3 2})\end{array}$ & $\begin{array}{c}\text { Manganese, } \\
\text { filtered, } \\
\mu \mathrm{g} / \mathrm{L} \\
(01056) \\
\end{array}$ & $\begin{array}{c}\text { Manganese, } \\
\text { unfiltered, } \\
\mu \mathrm{g} / \mathrm{L} \\
(01055)\end{array}$ \\
\hline \multicolumn{9}{|c|}{ Sand and gravel wells } \\
\hline CL151 & $<0.10$ & $<4.0$ & $<4$ & $<14$ & 0.35 & E0 .4 & $<0.2$ & $<0.4$ \\
\hline CL1500 & $<.10$ & E 2.3 & 6 & 75 & E .07 & 1.0 & 14.7 & 15.0 \\
\hline EX155 & $<.10$ & 25.9 & 25 & 42 & .24 & $<.6$ & 4.7 & 4.3 \\
\hline EX535 & .12 & $<4.0$ & 573 & 649 & .16 & 1.2 & 15.9 & 15.8 \\
\hline EX589 & E .08 & 6.7 & $<4$ & $<14$ & $<.10$ & $<.6$ & E. 2 & E.3 \\
\hline EX1013 & E.02 & $<1.4$ & 46 & 198 & $<.06$ & $<.3$ & 2.4 & 5.9 \\
\hline W534 & $<.10$ & $<4.0$ & $<4$ & $<14$ & .15 & 1.2 & 8.3 & 11.0 \\
\hline W1066 & $<.10$ & 16.8 & E 4 & 24 & E.07 & 1.7 & .3 & .5 \\
\hline \multicolumn{9}{|c|}{ Bedrock wells } \\
\hline CL149 & $<.04$ & $<1.4$ & 46 & 519 & E.04 & 14.0 & 135 & 205 \\
\hline CL154 & $<.10$ & 6.8 & 116 & 328 & 2.52 & 15.8 & 7.3 & 17.2 \\
\hline CL665 & $<.04$ & 10.4 & $<6$ & E 5 & E. 05 & 3.3 & $<.2$ & $<.8$ \\
\hline EX169 & $<.10$ & $<4.0$ & 5 & $<14$ & $<.10$ & 1.7 & 7.2 & 6.8 \\
\hline EX378 & E.03 & 2.2 & $<6$ & $<9$ & .26 & 1.1 & $<.2$ & $<.8$ \\
\hline EX664 & $<.10$ & E 3.7 & 6 & E 11 & .83 & 11.5 & .4 & 2.3 \\
\hline W1145 & E.04 & E 1.2 & 154 & 161 & .24 & 33.1 & 117 & 130 \\
\hline W1544 & .92 & 16.2 & $<4$ & 89 & 3.26 & 1.2 & E.1 & .6 \\
\hline WR86 & $<.04$ & $<1.4$ & $<6$ & 68 & .30 & 4.8 & .2 & 1.8 \\
\hline WR1326 & Е .09 & 24.9 & E 2 & E 10 & 2.13 & .7 & .6 & .8 \\
\hline WR1433 & $<.10$ & 37.1 & 4 & 215 & .97 & 62.7 & 9.9 & 11.6 \\
\hline WR1671 & E .07 & 6.0 & 13 & 382 & .77 & 3.6 & 59.0 & 56.4 \\
\hline
\end{tabular}

${ }^{1}$ CL, Clinton County; EX, Essex County; W, Washington County; WR, Warren County. 
Table 1-5. Concentrations of trace elements in groundwater samples collected in the Lake Champlain Basin, New York, 2009.-Continued

[ $\mu \mathrm{g} / \mathrm{L}$, micrograms per liter; (01105), U.S. Geological Survey National Water Information System parameter code; <, less than; E, estimated concentration. Well locations are shown in figure 2.]

\begin{tabular}{|c|c|c|c|c|c|c|}
\hline $\begin{array}{c}\text { Well } \\
\text { number } 1\end{array}$ & $\begin{array}{c}\text { Molybdenum, } \\
\text { unfiltered, } \\
\mu \mathrm{g} / \mathrm{L} \\
(\mathbf{0 1 0 6 2})\end{array}$ & $\begin{array}{c}\text { Nickel, } \\
\text { unfiltered, } \\
\mu \mathrm{g} / \mathrm{L} \\
(01067) \\
\end{array}$ & $\begin{array}{c}\text { Selenium, } \\
\text { unfiltered, } \\
\mu \mathrm{g} / \mathrm{L} \\
(01147)\end{array}$ & $\begin{array}{c}\text { Silver, } \\
\text { unfiltered, } \\
\mu \mathrm{g} / \mathrm{L} \\
(01077) \\
\end{array}$ & $\begin{array}{c}\text { Strontium, } \\
\text { unfiltered, } \\
\mu \mathrm{g} / \mathrm{L} \\
(01082) \\
\end{array}$ & $\begin{array}{c}\text { Zinc, } \\
\text { unfiltered, } \\
\mu \mathrm{g} / \mathrm{L} \\
(01092)\end{array}$ \\
\hline \multicolumn{7}{|c|}{ Sand and gravel wells } \\
\hline CL151 & 0.2 & $<0.20$ & $<0.12$ & $<0.06$ & 126 & 3.1 \\
\hline CL1500 & .2 & $<.20$ & $<.12$ & $<.06$ & 49.8 & 2.1 \\
\hline EX155 & .2 & $<.20$ & $<.12$ & $<.06$ & 32.0 & 8.4 \\
\hline EX535 & 1.8 & .36 & $<.12$ & $<.06$ & 118 & E 1.4 \\
\hline EX589 & .4 & 1.3 & E.06 & $<.06$ & 63.2 & 2.3 \\
\hline EX1013 & .2 & E.19 & Е .07 & $<.02$ & 35.2 & $<2.0$ \\
\hline W534 & .3 & $<.20$ & E.12 & $<.06$ & 236 & E 1.0 \\
\hline W1066 & .3 & E.13 & Е.09 & $<.06$ & 253 & 2.3 \\
\hline \multicolumn{7}{|c|}{ Bedrock wells } \\
\hline CL149 & 4.3 & .78 & $<.10$ & $<.02$ & 1,160 & 14.5 \\
\hline CL154 & 3.9 & .30 & $<.12$ & $<.06$ & 1,100 & 360 \\
\hline CL665 & 3.1 & $<.36$ & Е.09 & $<.02$ & 282 & 3.6 \\
\hline EX169 & .2 & E.18 & $<.12$ & $<.06$ & 177 & 2.5 \\
\hline EX378 & 2.1 & $<.36$ & .41 & $<.02$ & 226 & 4.7 \\
\hline EX664 & 7.3 & $<.20$ & $<.12$ & $<.06$ & 129 & 40.9 \\
\hline W1145 & 1.9 & E.28 & $<.10$ & E. 01 & 3,020 & E 1.5 \\
\hline W1544 & .3 & 3.4 & .18 & $<.06$ & 495 & 17.4 \\
\hline WR86 & 1.2 & $<.36$ & $<.10$ & $<.02$ & 168 & 32.3 \\
\hline WR1326 & .2 & .71 & $<.12$ & $<.06$ & 75.8 & 6.8 \\
\hline WR1433 & 1.2 & .54 & E.12 & $<.06$ & 1,280 & 10.6 \\
\hline WR1671 & 5.7 & .29 & $<.12$ & $<.06$ & 243 & 2.5 \\
\hline
\end{tabular}

${ }^{1}$ CL, Clinton County; EX, Essex County; W, Washington County; WR, Warren County. 
Table 1-6. Concentrations of pesticides and pesticide degradates detected in groundwater samples collected in the Lake Champlain Basin, New York, 2009.

[ $\mu \mathrm{g} / \mathrm{L}$, micrograms per liter; CIAT, 2-chloro-4-isopropylamino-6-amino-s-triazine (04040), U.S. Geological Survey National Water Information System parameter code; <, less than; E, estimated concentration; --, no data; M, presence verified but not quantified. Well locations are shown in figure 2.]

\begin{tabular}{|c|c|c|c|c|c|c|}
\hline $\begin{array}{c}\text { Well } \\
\text { number }{ }^{1}\end{array}$ & $\begin{array}{c}\text { CIAT, } \\
\text { filtered, } \\
\mu \mathrm{g} / \mathrm{L} \\
(04040) \\
\end{array}$ & $\begin{array}{c}\text { Atrazine, } \\
\text { filtered, } \\
\mu \mathrm{g} / \mathrm{L} \\
(39632)\end{array}$ & $\begin{array}{c}\text { Desulfinylfipronil, } \\
\text { filtered, } \\
\mu \mathrm{g} / \mathrm{L} \\
(62170) \\
\end{array}$ & $\begin{array}{c}\text { Disulfoton, } \\
\text { filtered, } \\
\mu \mathrm{g} / \mathrm{L} \\
(\mathbf{8 2 6 7 7 )} \\
\end{array}$ & $\begin{array}{c}\text { Fipronil, } \\
\text { filtered, } \\
\mu \mathrm{g} / \mathrm{L} \\
(62166)\end{array}$ & $\begin{array}{c}\text { Prometon, } \\
\text { filtered, } \\
\mu \mathrm{g} / \mathrm{L} \\
(04037) \\
\end{array}$ \\
\hline \multicolumn{7}{|c|}{ Sand and gravel wells } \\
\hline CL151 & $<0.014$ & $<0.007$ & $<0.012$ & $<0.04$ & $<0.040$ & $<0.01$ \\
\hline CL1500 & E.002 & $<.007$ & $<.012$ & $<.04$ & $<.040$ & $<.01$ \\
\hline EX155 & $<.014$ & $<.007$ & $<.012$ & $<.04$ & $<.040$ & $<.01$ \\
\hline EX535 & $<.014$ & $<.007$ & $<.012$ & $<.04$ & $<.040$ & $<.01$ \\
\hline EX589 & $<.014$ & $<.007$ & $<.012$ & $<.04$ & $<.040$ & $<.01$ \\
\hline EX1013 & $<.014$ & $<.007$ & $<.012$ & $<.04$ & $<.018$ & $<.01$ \\
\hline W534 & E.001 & $<.007$ & $<.012$ & $<.04$ & $<.040$ & $<.01$ \\
\hline W1066 & $<.014$ & $<.007$ & $<.012$ & $<.04$ & $<.040$ & $<.01$ \\
\hline \multicolumn{7}{|c|}{ Bedrock wells } \\
\hline CL149 & $<.014$ & $<.007$ & $<.012$ & $<.04$ & $<.018$ & $<.01$ \\
\hline CL154 & $<.014$ & $<.007$ & $<.012$ & $<.04$ & $<.040$ & $<.01$ \\
\hline CL665 & $<.014$ & $<.007$ & $<.012$ & $<.04$ & $<.018$ & $<.01$ \\
\hline EX169 & $<.014$ & $<.007$ & $<.012$ & $<.04$ & $<.040$ & $<.01$ \\
\hline EX378 & E.002 & E.002 & E.001 & $<.04$ & E.002 & $<.01$ \\
\hline EX664 & -- & -- & -- & -- & -- & -- \\
\hline W1145 & $<.014$ & $<.007$ & $<.012$ & $<.04$ & $<.018$ & $<.01$ \\
\hline W1544 & E.003 & E.002 & $<.012$ & $<.04$ & $<.040$ & M \\
\hline WR86 & $<.014$ & $<.007$ & $<.012$ & $<.04$ & $<.018$ & $<.01$ \\
\hline WR1326 & $<.014$ & $<.007$ & $<.012$ & E.02 & $<.040$ & $<.01$ \\
\hline WR1433 & $<.014$ & $<.007$ & $<.012$ & $<.04$ & $<.040$ & $<.01$ \\
\hline WR1671 & $<.014$ & $<.007$ & $<.012$ & $<.04$ & $<.040$ & $<.01$ \\
\hline
\end{tabular}

${ }^{1}$ CL, Clinton County; EX, Essex County; W, Washington County; WR, Warren County. 
Table 1-7. Concentrations of volatile organic compounds detected in groundwater samples collected in the Lake Champlain Basin, New York, 2009.

[ $\mu \mathrm{g} / \mathrm{L}$, micrograms per liter; (34501), U.S. Geological Survey National Water Information System parameter code; <, less than. Well locations are shown in figure 2.]

\begin{tabular}{|c|c|c|c|c|c|c|}
\hline Well number ${ }^{1}$ & $\begin{array}{c}1,1- \\
\text { Dichloro- } \\
\text { ethene, } \\
\text { unfiltered, } \\
\mu \mathrm{g} / \mathrm{L} \\
(\mathbf{3 4 5 0 1 )}\end{array}$ & $\begin{array}{c}\text { Bromo- } \\
\text { dichloro- } \\
\text { methane, } \\
\text { unfiltered, } \\
\mu \mathrm{g} / \mathrm{L} \\
(\mathbf{3 2 1 0 1 )}\end{array}$ & $\begin{array}{c}\text { Tribromo- } \\
\text { methane, } \\
\text { unfiltered, } \\
\mu \mathrm{g} / \mathrm{L} \\
(32104)\end{array}$ & $\begin{array}{c}\text { Dibromo- } \\
\text { chloro- } \\
\text { methane, } \\
\text { unfiltered, } \\
\mu \mathrm{g} / \mathrm{L} \\
(32105)\end{array}$ & $\begin{array}{c}\text { Methyl tert- } \\
\text { butyl ether, } \\
\text { unfiltered, } \\
\mu \mathrm{g} / \mathrm{L} \\
(78032)\end{array}$ & $\begin{array}{c}\text { Trichloro- } \\
\text { methane, } \\
\text { unfiltered, } \\
\mu \mathrm{g} / \mathrm{L} \\
(32106)\end{array}$ \\
\hline \multicolumn{7}{|c|}{ Sand and gravel wells } \\
\hline CL151 & $<0.1$ & $<0.1$ & $<0.2$ & $<0.2$ & $<0.2$ & $<0.1$ \\
\hline CL1500 & $<.1$ & $<.1$ & $<.2$ & $<.2$ & $<.2$ & $<.1$ \\
\hline EX155 & $<.1$ & $<.1$ & $<.2$ & $<.2$ & $<.2$ & $<.1$ \\
\hline EX535 & $<.1$ & $<.1$ & $<.2$ & $<.2$ & $<.2$ & $<.1$ \\
\hline EX589 & .3 & $<.1$ & $<.2$ & $<.2$ & $<.2$ & $<.1$ \\
\hline EX1013 & $<.1$ & $<.1$ & $<.2$ & $<.2$ & $<.2$ & $<.1$ \\
\hline W534 & $<.1$ & $<.1$ & $<.2$ & $<.2$ & $<.2$ & $<.1$ \\
\hline W1066 & $<.1$ & $<.1$ & $<.2$ & $<.2$ & $<.2$ & $<.1$ \\
\hline \multicolumn{7}{|l|}{ Bedrock wells } \\
\hline CL149 & $<.1$ & 1.7 & 11.8 & 7.8 & .9 & .3 \\
\hline CL154 & $<.1$ & 4.4 & 2.4 & 4.5 & $<.2$ & 5.0 \\
\hline CL665 & $<.1$ & $<.1$ & $<.2$ & $<.2$ & $<.2$ & $<.1$ \\
\hline EX169 & $<.1$ & $<.1$ & $<.2$ & $<.2$ & $<.2$ & $<.1$ \\
\hline EX378 & $<.1$ & $<.1$ & $<.2$ & $<.2$ & $<.2$ & $<.1$ \\
\hline EX664 & $<.1$ & $<.1$ & $<.2$ & $<.2$ & $<.2$ & $<.1$ \\
\hline W1145 & $<.1$ & $<.1$ & $<.2$ & $<.2$ & $<.2$ & $<.1$ \\
\hline W1544 & $<.1$ & $<.1$ & $<.2$ & $<.2$ & $<.2$ & .3 \\
\hline WR86 & $<.1$ & $<.1$ & $<.2$ & $<.2$ & $<.2$ & .3 \\
\hline WR1326 & $<.1$ & $<.1$ & $<.2$ & $<.2$ & $<.2$ & $<.1$ \\
\hline WR1433 & $<.1$ & $<.1$ & $<.2$ & $<.2$ & $<.2$ & $<.1$ \\
\hline WR1671 & $<.1$ & $<.1$ & $<.2$ & $<.2$ & 6.0 & $<.1$ \\
\hline
\end{tabular}

${ }^{1}$ CL, Clinton County; EX, Essex County; W, Washington County; WR, Warren County. 
Table 1-8. Activities of radionuclides in groundwater samples from the Lake Champlain Basin, New York, 2009. [pCi/L, picocuries per liter; $\mu \mathrm{g} / \mathrm{L}$, micrograms per liter; (01519), USGS National Water Information System parameter code; $<$, less than. Bold values equal or exceed one or more existing or proposed drinking-water standards. Well locations are shown in figure 2]

\begin{tabular}{|c|c|c|c|c|}
\hline $\begin{array}{c}\text { Well } \\
\text { number }{ }^{1}\end{array}$ & $\begin{array}{c}\text { Gross alpha } \\
\text { radioactivity, } \\
\text { unfiltered, } \\
\text { pCi/L } \\
(01519) \\
\end{array}$ & $\begin{array}{c}\text { Gross beta } \\
\text { radioactivity, } \\
\text { unfiltered, } \\
\text { pCi/L } \\
(85817)\end{array}$ & $\begin{array}{c}\text { Radon-222, } \\
\text { unfiltered, } \\
\text { pCi/L } \\
(82303) \\
\end{array}$ & $\begin{array}{c}\text { Uranium, } \\
\text { unfiltered, } \\
\mu \mathrm{g} / \mathrm{L} \\
(28011)\end{array}$ \\
\hline \multicolumn{5}{|c|}{ Sand and gravel wells } \\
\hline CL151 & 1.6 & 1.1 & 151 & 0.466 \\
\hline CL1500 & .7 & 1.1 & 370 & .158 \\
\hline EX155 & $<.55$ & $<.88$ & 72 & Е.012 \\
\hline EX535 & 2.0 & .9 & 143 & .585 \\
\hline EX589 & $<.56$ & $<.85$ & 159 & .222 \\
\hline EX1013 & $<.57$ & $<.82$ & 86 & .045 \\
\hline W534 & $<1.3$ & $<1.2$ & 340 & .475 \\
\hline W1066 & 1.2 & $<.93$ & 380 & .249 \\
\hline \multicolumn{5}{|c|}{ Bedrock wells } \\
\hline CL149 & 3.1 & 9.3 & 154 & .439 \\
\hline CL154 & 15 & 9.7 & 320 & 3.07 \\
\hline CL665 & 1.3 & 2.9 & 550 & 2.60 \\
\hline EX169 & $<.81$ & 1.6 & 159 & .173 \\
\hline EX378 & $<1.2$ & $<1.1$ & 19 & 1.81 \\
\hline EX664 & 10.6 & 1.9 & 1,230 & 6.41 \\
\hline W1145 & 1.3 & 7.9 & 108 & 4.12 \\
\hline W1544 & $<1.6$ & 1.5 & 390 & .388 \\
\hline WR86 & 5.3 & 4.4 & 4,100 & 4.80 \\
\hline WR1326 & 1.1 & $<1.1$ & 820 & .069 \\
\hline WR1433 & $<2.2$ & 1.3 & 34 & .602 \\
\hline WR1671 & 7.5 & 2.5 & 700 & 2.61 \\
\hline
\end{tabular}

${ }^{1}$ CL, Clinton County; EX, Essex County; W, Washington County; WR, Warren County. 
Table 1-9. Bacteria in groundwater samples collected in the Lake Champlain Basin, New York, 2009.

[CFU, colony-forming unit; mL, milliliter; (31691), U.S. Geological Survey National Water Information System parameter code; < less than. Bold values indicate detections of coliform bacteria. Well locations are shown in figure 2]

\begin{tabular}{|c|c|c|c|c|}
\hline $\begin{array}{c}\text { Well } \\
\text { number }^{1}\end{array}$ & $\begin{array}{l}\text { Escherichia } \\
\text { coli, } \\
\text { unfiltered, } \\
\text { CFU/100mL } \\
\text { (31691) }\end{array}$ & $\begin{array}{l}\text { Fecal coliform, } \\
\text { unfiltered, } \\
\text { CFU/100mL } \\
(61215)\end{array}$ & $\begin{array}{l}\text { Heterotrophic } \\
\text { plate count, } \\
\text { unfiltered, } \\
\text { CFU/mL } \\
\text { (31692) }\end{array}$ & $\begin{array}{l}\text { Total coliform, } \\
\text { unfiltered, } \\
\text { CFU/100mL } \\
\text { (61213) }\end{array}$ \\
\hline \multicolumn{5}{|c|}{ Sand and gravel wells } \\
\hline CL151 & $<1$ & $<1$ & 2 & $<1$ \\
\hline CL1500 & $<1$ & $<1$ & 8 & $<1$ \\
\hline EX155 & $<1$ & $<1$ & 3 & $<1$ \\
\hline EX535 & $<1$ & 1 & 23 & $<1$ \\
\hline EX589 & $<1$ & $<1$ & 9 & $<1$ \\
\hline EX1013 & $<1$ & $<1$ & 34 & 42 \\
\hline W534 & $<1$ & $<1$ & 5 & $<1$ \\
\hline W1066 & $<1$ & $<1$ & 25 & $<1$ \\
\hline \multicolumn{5}{|c|}{ Bedrock wells } \\
\hline CL149 & $<1$ & $<1$ & 7 & $<1$ \\
\hline CL154 & $<1$ & $<1$ & 2 & $<1$ \\
\hline CL665 & $<1$ & $<1$ & 8 & $<1$ \\
\hline EX169 & $<1$ & $<1$ & 13 & $<1$ \\
\hline EX378 & $<1$ & $<1$ & 5 & 4 \\
\hline EX664 & $<1$ & $<1$ & 11 & $<1$ \\
\hline W1145 & $<1$ & $<1$ & $<1$ & $<1$ \\
\hline W1544 & $<1$ & $<1$ & 7 & 3 \\
\hline WR86 & $<1$ & $<1$ & $<1$ & $<1$ \\
\hline WR1326 & $<1$ & $<1$ & 11 & $<1$ \\
\hline WR1433 & $<1$ & $<1$ & 8 & 1 \\
\hline WR1671 & $<1$ & $<1$ & 18 & $<1$ \\
\hline
\end{tabular}

${ }^{1}$ CL, Clinton County; EX, Essex County; W, Washington County; WR, Warren County. 


\section{Appendix 2: Comparison of Data from 2004 and 2009}

The following tables summarize results of the chemical analyses of the samples collected in 2004 and 2009 from four wells in the Lake Champlain Basin of eastern New York.

2-1. Physiochemical properties and concentrations of major ions, nutrients, and bacteria in groundwater samples collected in the Lake Champlain Basin, New York, 2004 and 2009.

2-2. Concentrations of trace elements and radionuclides in groundwater samples collected in the Lake Champlain Basin, New York, 2004 and 2009.

2-3. Concentrations of pesticides in groundwater samples collected in the Lake Champlain Basin, New York, 2004 and 2009

2-4. Concentrations of volatile organic compounds in groundwater samples collected in the Lake Champlain Basin, New York, 2004 and 2009. 
Table 2-1. Physiochemical properties and concentrations of major ions, nutrients, and bacteria in groundwater samples collected in the Lake Champlain Basin, New York, 2004 and 2009.

[NWIS, National Water Information System; wu, unfiltered water; wf, filtered water; mg/L, milligrams per liter; $\mu \mathrm{S} / \mathrm{cm}$, microsiemens per centimeter at 25 degrees Celsius; $\mathrm{CaCO}_{3}$, calcium carbonate; ${ }^{\circ} \mathrm{C}$, Celsius; $\mathrm{N}$, nitrogen; $\mathrm{P}$, phosphorus; $\mathrm{CFU}$, colony-forming unit; $\mathrm{mL}$, milliliter; <, less than, E, estimated concentration; lab, laboratory]

\begin{tabular}{|c|c|c|c|c|c|c|c|c|c|}
\hline $\begin{array}{c}\text { U.S. Geological } \\
\text { Survey NWIS } \\
\text { parameter code }\end{array}$ & Constituent & \multicolumn{2}{|c|}{ Well EX 155} & \multicolumn{2}{|c|}{ Well EX 535} & \multicolumn{2}{|c|}{ Well W 534} & \multicolumn{2}{|c|}{ Well CL 149} \\
\hline 00080 & Color, wf, platinum-cobalt units & 2 & $<1$ & 18 & 2 & 2 & 2 & 15 & 20 \\
\hline 00300 & Dissolved oxygen, wu, mg/L & 4.0 & 5.4 & $<.1$ & 1.6 & 5.3 & 3.3 & 1.0 & .3 \\
\hline 00400 & $\mathrm{pH}, \mathrm{wu}$ & 6.6 & 7.0 & 7.3 & 7.0 & 7.2 & 6.8 & 7.4 & 7.2 \\
\hline 00900 & Hardness, wf, mg/L as $\mathrm{CaCO}_{3}$ & 50 & 31 & 290 & 250 & 250 & 210 & 310 & 320 \\
\hline 00915 & Calcium, wf, mg/L & 14.5 & 8.68 & 66.6 & 57.1 & 67.5 & 55.9 & 65.8 & 69.2 \\
\hline 00925 & Magnesium, wf, mg/L & 3.33 & 2.37 & 30.2 & 27.0 & 19.6 & 16.6 & 35.8 & 35.0 \\
\hline 00935 & Potassium, wf, mg/L & .47 & .54 & .86 & .78 & .97 & .79 & 9.25 & 8.85 \\
\hline 29801 & $\begin{array}{l}\text { Alkalinity, wf, fixed end point, } \\
\text { laboratory, mg/L as } \mathrm{CaCO}_{3}\end{array}$ & 34 & 29 & 235 & 216 & 210 & 192 & 253 & 264 \\
\hline 29805 & $\begin{array}{l}\text { Bicarbonate, wf, fixed end point, } \\
\text { laboratory, mg/L }\end{array}$ & 41 & 35 & 287 & 264 & 256 & 234 & 309 & 322 \\
\hline 00940 & Chloride, wf, mg/L & 8.29 & 1.67 & .76 & .74 & 4.67 & 6.46 & 189 & 193 \\
\hline 00950 & Fluoride, wf, mg/L & $<.17$ & $<.08$ & $<.17$ & Е .07 & $<.17$ & E .08 & $<.17$ & .15 \\
\hline 00955 & Silica, wf, mg/L & 22.1 & 18.4 & 18.0 & 15.4 & 12.3 & 10.5 & 9.19 & 8.68 \\
\hline 00945 & Sulfate, wf, mg/L & 7.33 & 7.90 & 30.7 & 29.6 & 31.5 & 23.2 & 97.6 & 89.4 \\
\hline 70300 & $\begin{array}{l}\text { Dissolved solids, } \\
\text { dried at } 180^{\circ} \mathrm{C} \text {, wf, mg/L }\end{array}$ & 82 & 65 & 289 & 268 & 264 & 236 & 703 & 700 \\
\hline 00680 & Organic carbon, wu, mg/L & 1.35 & .7 & E 1.42 & E.5 & 1.21 & E .5 & 2.01 & 1.3 \\
\hline 31691 & $\begin{array}{l}\text { Escherichia coli, wu, CFU per } \\
100 \mathrm{~mL}\end{array}$ & $<1$ & $<1$ & $<1$ & $<1$ & $<1$ & $<1$ & $<1$ & $<1$ \\
\hline 61215 & $\begin{array}{l}\text { Fecal coliform, wu, CFU per } 100 \\
\text { mL }\end{array}$ & $<1$ & $<1$ & $<1$ & 1 & $<1$ & $<1$ & $<1$ & $<1$ \\
\hline 31692 & $\begin{array}{l}\text { Heterotrophic plate count, wu, } \\
\text { CFU per mL }\end{array}$ & 1 & 3 & 1 & 23 & 8 & 5 & 3 & 7 \\
\hline 61213 & $\begin{array}{l}\text { Total coliform, wu, CFU per } 100 \\
\text { mL }\end{array}$ & $<1$ & $<1$ & $<1$ & $<1$ & $<1$ & $<1$ & $<1$ & $<1$ \\
\hline
\end{tabular}


Table 2-2. Concentrations of trace elements and radionuclides in groundwater samples collected in the Lake Champlain Basin, New York, 2004 and 2009.

[NWIS, National Water Information System; wu, unfiltered water; wf, filtered water; $\mu \mathrm{g} / \mathrm{L}$, micrograms per liter, pCi/L, picocuries per liter; $<$, less than, E, estimated concentration]

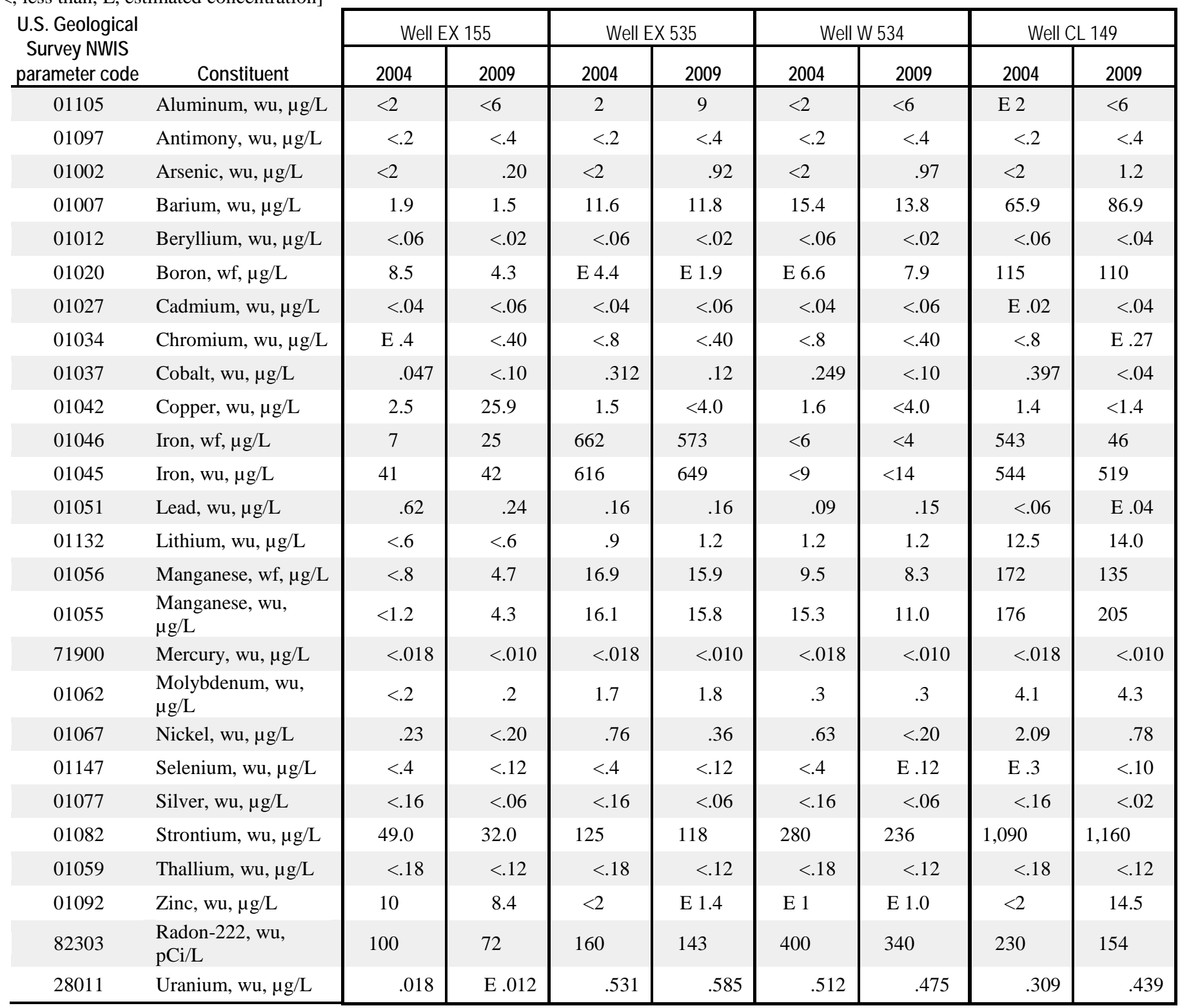


Table 2-3. Concentrations of pesticides in groundwater samples collected in the Lake Champlain Basin, New York, 2004 and 2009.

[NWIS, National Water Information System; wf, filtered water; $\mu \mathrm{g} / \mathrm{L}$, micrograms per liter, <, less than, E, estimated concentration. Bold value indicates detected concentration.]

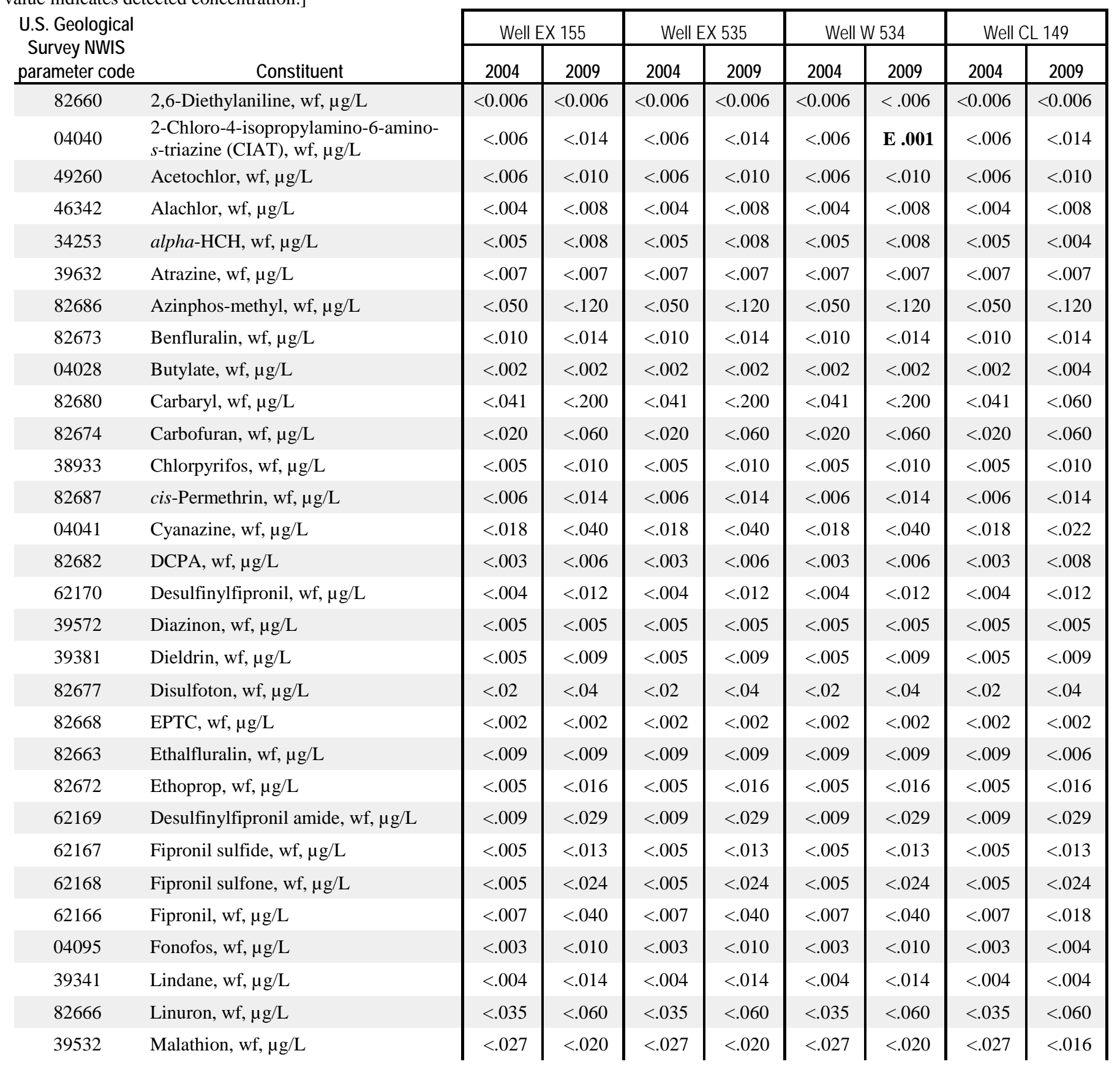


Table 2-3. Concentrations of pesticides in groundwater samples collected in the Lake Champlain Basin, New York, 2004 and 2009. - Continued

[NWIS, National Water Information System; wf, filtered water; $\mu \mathrm{g} / \mathrm{L}$, micrograms per liter, <, less than, E, estimated concentration. Bold values indicate detections.]

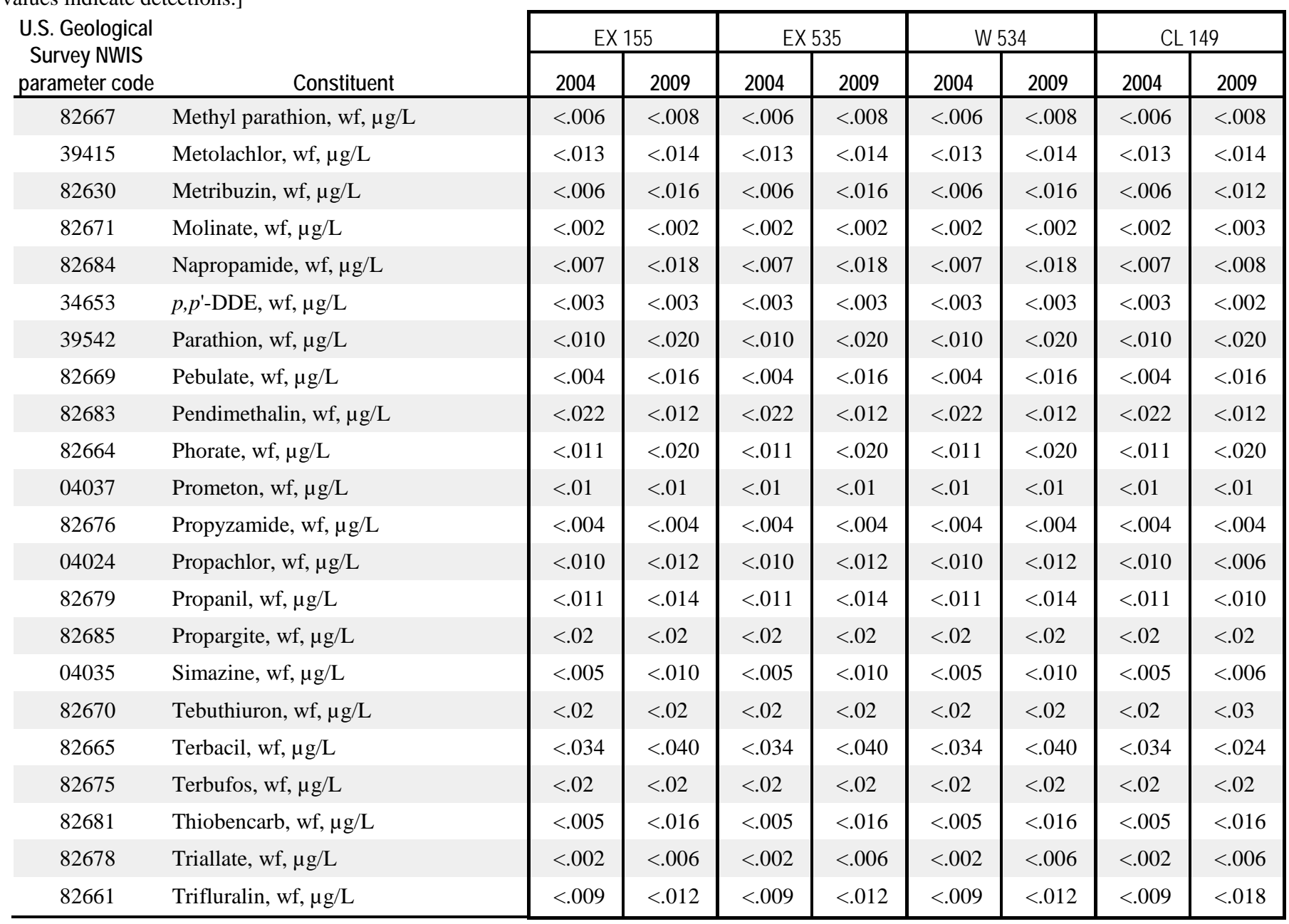


Table 2-4. Concentrations of volatile organic compounds in groundwater samples collected in the Lake Champlain Basin, New York, 2004 and 2009.

[NWIS, National Water Information System; wu, unfiltered water; $\mu \mathrm{g} / \mathrm{L}$, micrograms per liter; $<$, less than. Bold values indicate detected concentrations.]

\begin{tabular}{|c|c|c|c|c|c|c|c|c|c|}
\hline \multirow{2}{*}{$\begin{array}{l}\text { U.S. Geological } \\
\text { Survey NWIS } \\
\text { parameter code } \\
\end{array}$} & \multirow[b]{2}{*}{ Constituent } & \multicolumn{2}{|c|}{ EX 155} & \multicolumn{2}{|c|}{ EX 535} & \multicolumn{2}{|c|}{ W 534} & \multicolumn{2}{|c|}{ CL 149} \\
\hline & & 2004 & 2009 & 2004 & 2009 & 2004 & 2009 & 2004 & 2009 \\
\hline 34506 & 1,1,1-Trichloroethane, wu, $\mu \mathrm{g} / \mathrm{L}$ & $<0.1$ & $<0.1$ & $<0.1$ & $<0.1$ & $<0.1$ & $<0.1$ & $<0.1$ & $<0.1$ \\
\hline 77652 & $\begin{array}{l}\text { 1,1,2-Trichloro-1,2,2- } \\
\text { trifluoroethane (CFC-113), wu, } \\
\mu \mathrm{g} / \mathrm{L}\end{array}$ & $<.1$ & $<.1$ & $<.1$ & $<.1$ & $<.1$ & $<.1$ & $<.1$ & $<.1$ \\
\hline 34536 & 1,2-Dichlorobenzene, wu, $\mu \mathrm{g} / \mathrm{L}$ & $<.1$ & $<.1$ & $<.1$ & $<.1$ & $<.1$ & $<.1$ & $<.1$ & $<.1$ \\
\hline 32103 & 1,2-Dichloroethane, wu, $\mu \mathrm{g} / \mathrm{L}$ & $<.2$ & $<.2$ & $<.2$ & $<.2$ & $<.2$ & $<.2$ & $<.2$ & $<.2$ \\
\hline 34541 & 1,2-Dichloropropane, wu, $\mu \mathrm{g} / \mathrm{L}$ & $<.1$ & $<.1$ & $<.1$ & $<.1$ & $<.1$ & $<.1$ & $<.1$ & $<.1$ \\
\hline 34566 & 1,3-Dichlorobenzene, wu, $\mu \mathrm{g} / \mathrm{L}$ & $<.1$ & $<.1$ & $<.1$ & $<.1$ & $<.1$ & $<.1$ & $<.1$ & $<.1$ \\
\hline 32101 & Bromodichloromethane, wu, $\mu \mathrm{g} / \mathrm{L}$ & $<.1$ & $<.1$ & $<.1$ & $<.1$ & $<.1$ & $<.1$ & $<.1$ & 1.7 \\
\hline 32104 & Tribromomethane, wu, $\mu \mathrm{g} / \mathrm{L}$ & $<.2$ & $<.2$ & $<.2$ & $<.2$ & $<.2$ & $<.2$ & $<.2$ & 11.8 \\
\hline 34301 & Chlorobenzene, wu, $\mu \mathrm{g} / \mathrm{L}$ & $<.1$ & $<.1$ & $<.1$ & $<.1$ & $<.1$ & $<.1$ & $<.1$ & $<.1$ \\
\hline 77093 & cis-1,2-Dichloroethene, wu, $\mu \mathrm{g} / \mathrm{L}$ & $<.1$ & $<.1$ & $<.1$ & $<.1$ & $<.1$ & $<.1$ & $<.1$ & $<.1$ \\
\hline 32105 & Dibromochloromethane, wu, $\mu \mathrm{g} / \mathrm{L}$ & $<.2$ & $<.2$ & $<.2$ & $<.2$ & $<.2$ & $<.2$ & $<.2$ & 7.8 \\
\hline 34668 & Dichlorodifluoromethane, wu, $\mu \mathrm{g} / \mathrm{L}$ & $<.2$ & $<.2$ & $<.2$ & $<.2$ & $<.2$ & $<.2$ & $<.2$ & $<.2$ \\
\hline 34423 & Dichloromethane, wu, $\mu \mathrm{g} / \mathrm{L}$ & $<.2$ & $<.2$ & $<.2$ & $<.2$ & $<.2$ & $<.2$ & $<.2$ & $<.2$ \\
\hline 81576 & Diethyl ether, wu, $\mu \mathrm{g} / \mathrm{L}$ & $<.2$ & $<.2$ & $<.2$ & $<.2$ & $<.2$ & $<.2$ & $<.2$ & $<.2$ \\
\hline 81577 & Diisopropyl ether, wu, $\mu \mathrm{g} / \mathrm{L}$ & $<.2$ & $<.2$ & $<.2$ & $<.2$ & $<.2$ & $<.2$ & $<.2$ & $<.2$ \\
\hline 50004 & tert-Butyl ethyl ether, wu, $\mu \mathrm{g} / \mathrm{L}$ & $<.1$ & $<.1$ & $<.1$ & $<.1$ & $<.1$ & $<.1$ & $<.1$ & $<.1$ \\
\hline 78032 & $\begin{array}{l}\text { Methyl tert-butyl ether (MTBE), } \\
\text { wu, } \mu \mathrm{g} / \mathrm{L}\end{array}$ & $<.2$ & $<.2$ & $<.2$ & $<.2$ & $<.2$ & $<.2$ & .7 & .9 \\
\hline 34475 & Tetrachloroethene, wu, $\mu \mathrm{g} / \mathrm{L}$ & $<.1$ & $<.1$ & $<.1$ & $<.1$ & $<.1$ & $<.1$ & $<.1$ & $<.1$ \\
\hline 32102 & Tetrachloromethane, wu, $\mu \mathrm{g} / \mathrm{L}$ & $<.2$ & $<.2$ & $<.2$ & $<.2$ & $<.2$ & $<.2$ & $<.2$ & $<.2$ \\
\hline 34010 & Toluene, wu, $\mu \mathrm{g} / \mathrm{L}$ & $<.1$ & $<.1$ & $<.1$ & $<.1$ & $<.1$ & $<.1$ & $<.1$ & $<.1$ \\
\hline 34546 & trans-1,2-Dichloroethene, wu, $\mu \mathrm{g} / \mathrm{L}$ & $<.1$ & $<.1$ & $<.1$ & $<.1$ & $<.1$ & $<.1$ & $<.1$ & $<.1$ \\
\hline 39180 & Trichloroethene, wu, $\mu \mathrm{g} / \mathrm{L}$ & $<.1$ & $<.1$ & $<.1$ & $<.1$ & $<.1$ & $<.1$ & $<.1$ & $<.1$ \\
\hline 34488 & $\begin{array}{l}\text { Trichlorofluoromethane (CFC-11), } \\
\text { wu, } \mu \mathrm{g} / \mathrm{L}\end{array}$ & $<.2$ & $<.2$ & $<.2$ & $<.2$ & $<.2$ & $<.2$ & $<.2$ & $<.2$ \\
\hline 32106 & Trichloromethane, wu, $\mu \mathrm{g} / \mathrm{L}$ & $<.1$ & $<.1$ & $<.1$ & $<.1$ & $<.1$ & $<.1$ & $<.1$ & .3 \\
\hline 39175 & Vinyl chloride, wu, $\mu \mathrm{g} / \mathrm{L}$ & $<.2$ & $<.2$ & $<.2$ & $<.2$ & $<.2$ & $<.2$ & $<.2$ & $<.2$ \\
\hline
\end{tabular}


For more information concerning this report, contact

Director

U.S. Geological Survey

New York Water Science Center

425 Jordan Road

Troy, NY 12180-8349

dc_ny@usgs.gov

or visit our Web site at:

http://ny.water.usgs.gov 


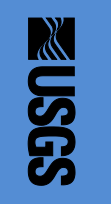

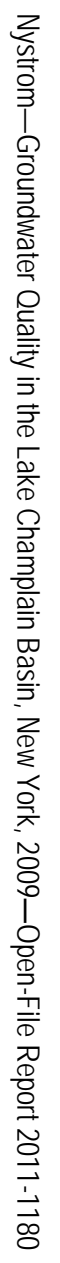

